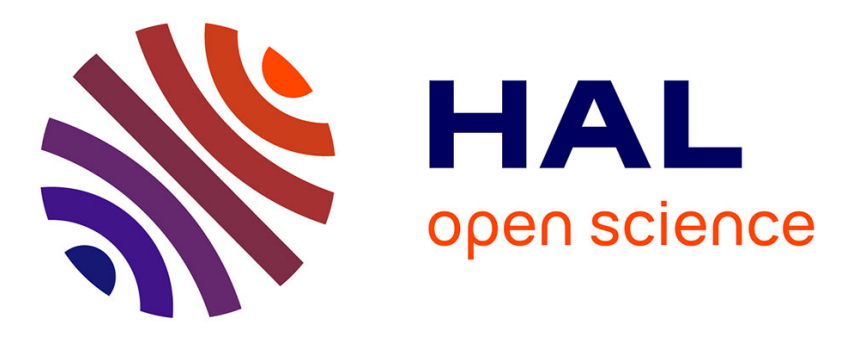

\title{
Molecular Engineering onto Ru-II \\ Bis(1,2-diphenylphosphinoethane) Synthon: Toward an Original Organometallic Gelator
}

Olivier Galangau, Dania Daou, Nour El Beyrouti, Elsa Caytan, Cristelle Mériadec, Franck Artzner, Stéphane Rigaut

\section{To cite this version:}

Olivier Galangau, Dania Daou, Nour El Beyrouti, Elsa Caytan, Cristelle Mériadec, et al.. Molecular Engineering onto Ru-II Bis(1,2-diphenylphosphinoethane) Synthon: Toward an Original Organometallic Gelator. Inorganic Chemistry, 2021, 60 (15), pp.11474-11484. 10.1021/acs.inorgchem.1c01488 . hal-03330805

\section{HAL Id: hal-03330805 https://hal.science/hal-03330805}

Submitted on 11 Oct 2021

HAL is a multi-disciplinary open access archive for the deposit and dissemination of scientific research documents, whether they are published or not. The documents may come from teaching and research institutions in France or abroad, or from public or private research centers.
L'archive ouverte pluridisciplinaire HAL, est destinée au dépôt et à la diffusion de documents scientifiques de niveau recherche, publiés ou non, émanant des établissements d'enseignement et de recherche français ou étrangers, des laboratoires publics ou privés. 


\title{
Molecular Engineering onto $\mathrm{Ru}^{\mathrm{II}}$ bis(1,2-diphenylphosphinoethane) synthon: toward a new family of organometallic gelator.
}

\author{
O. Galangau,${ }^{\dagger *}$ D. Daou,${ }^{\dagger}$ N. El Beyrouti,${ }^{\dagger}$ E. Caytan,${ }^{\dagger}$ C. Meriadec,${ }^{\dagger}$ F. Artzner,${ }^{\ddagger}$ S. Rigaut ${ }^{\dagger *}$ \\ tUniv Rennes, CNRS, ISCR (Institut des Sciences Chimiques de Rennes) - UMR 6226, F-35000 Rennes, France \\ ¥Univ Rennes, CNRS, IPR (Institut de Physique de Rennes) - UMR 6251, F-35000 Rennes, France \\ Supporting Information Placeholder
}

\begin{abstract}
In this article we report the successful molecular engineering of Ru bis-acetylides that led for the first time to gelators, and more specifically in aromatic solvents. By means of a non-linear ligand and an extended aromatic platform, the bulky Ru bisacetylides were able to self-assemble into lamellar structures as evidenced by SEM in benzene, toluene, o-and m-xylene, which in turn induced gelation of the solution with critical gelation concentration of $30 \mathrm{mg} / \mathrm{mL}$. NMR, VT-NMR, FT-IR spectroscopies evidenced that hydrogen bonds are mainly responsible for the self-organization. VT-NMR and SAXS have also suggested that the pro-ligand and the complex stack in different ways.
\end{abstract}

\section{INTRODUCTION}

Supramolecular interactions are key features to obtain (multi-) functional materials with applications ranging from optoelectronics $^{1}, \underline{2}$ to molecular electronics. $\underline{\underline{3-5}}$ To that regard, molecular gels $\underline{6}$ have received a great deal of attention in the last decade for their appealing properties which have permitted developments of materials with high chemical sensing abilities, $\frac{7-10}{-}$ remarkable charge transport properties, $\underline{11}$ photochemical and electrochemical responsiveness. $. \underline{10}, \underline{12-14}$ Gels can be defined as soft materials made of a liquid phase (major component) immobilized in a 3D cross-linked network (minor component). This network can be made of covalent polymeric chains or prepared from the supramolecular assembly of a low molecular weight compound, both being known as the gelator. For the so-called supramolecular gels, the gelator self-assembles thanks to a combination of weak interaction such as Van der Waals or electrostatic interactions, hydrogen/halogen bonding and/or $\pi-\pi$ stacking interactions. A gel is commonly identified by the test inversion method which consists in looking at the ability of the soft material to support its own weight when the vial is turned upside-down. Therefore, a gel can be interpreted as a clear sign of self-assembly properties whereas the lack of gelation may stem from a limited propensity to form supramolecular polymers. Recently, metallogels $\frac{15-18}{}$ where the gelator is either a coordination or an organometallic derivative have drawn a lot of attention. Indeed, the presence of the metal has brought about new features such as redox responses, $\frac{19}{\text { luminescence }} \underline{20}$ or cat-

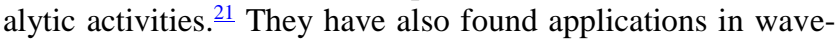
guiding $\underline{22}$ or as anticancer treatments. $\frac{23}{}$ Among all metallogelators, rigid rod-like metal-acetylides, where the metal is $\mathrm{Pt}(\mathrm{II})^{24-}$ $\underline{27}$ or $\mathrm{Au}(\mathrm{III}), \underline{28}$ are efficient gelators thanks to their flat structures, and for $\mathrm{Pt}(\mathrm{II})$ centers, their ability to provide additional Metal-Metal interactions $\underline{29}, \underline{30}$ that are further driving the supramolecular assembly. Because of their photophysical properties, those metal-acetylides metallogels were mainly use as light emitting soft materials. Alternatively, metallogels transporting electrical charges are well desired for the development of flexible, lightweight, electronic devices, although examples were scarcely documented so far. $\stackrel{31}{ }$ To obtain rigid-rod conductive supramolecular metallogels, organometallic acetylides gelators must combine strong supramolecular abilities to low potential and reversible redox processes.

Chart 1. Molecular structures of $R u_{1}$ and $R u_{2}$ complexes
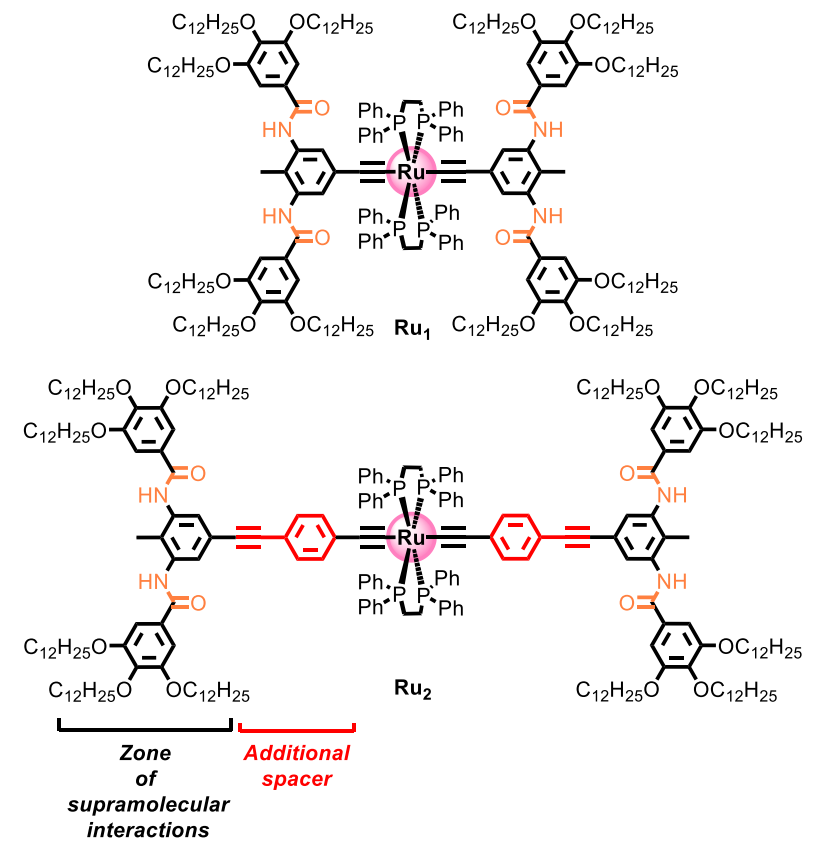
Our group, among others, has been involved in the chemistry of mono- and bimetallic $\mathrm{Ru}$ (II) bis-acetylide complexes holding great promises for optoelectronic applications. Indeed, these compounds feature remarkable charge transport properties in nanojunctions $\frac{32-41}{}$, on gold surfaces as charges storage layer ${ }^{42}$ or as "push-pull" chromophoric reagents for solar cells $\underline{43}$ and NLO applications. $\frac{44-48}{}$ Recently, we also reported $\mathrm{Ru}$ bis-acetylides as efficient electrochemical switch for lanthanide emission in the NIR ranges $\underline{49}, \underline{50}$ or magnetic properties. $\underline{51}$ However, to the best of our knowledge, there is no example of mono- or bimetallic $\mathrm{Ru}(\mathrm{II})$ bis-acetylide derivatives able to form supramolecular assemblies / gels, that would widen their application field, thanks to their unique electronic properties. This statement presumably result from the fact that the stabilizing 1,2-dppe ancillary ligands prevent accurate intermolecular contacts. $\stackrel{52}{ }$ Therefore, designing $\mathrm{Ru}(\mathrm{II})$ bis-acetylide complexes able to overcome this drawback and form supramolecular architectures accommodating its bulky ligands is challenging.

We anticipated that placing an acetylide ligand, featuring a simple hydrogen donating/accepting moiety in trans position with respect to the metal center, would not be sufficient for driving self-assembling, as it is for $\mathrm{Pt}(\mathrm{II})$ bis-acetylides $\frac{22}{2}$ derivatives. Therefore, we selected a ligand that could trigger gelation of alkane solvents, while connected to a bulky coordination sphere, such as those used in the Ln(III) complexes developed by Ziessel, Camerel, Charbonnière. $\underline{53}-\underline{54}$ This ligand encompasses a central toluyl fragment connected to two amide functions that, on the basis of crystallographic data, was found to pack in a head-to-tail fashion with a molecular packing driven by hydrogen bonding interactions. The toluyl fragment is essential since it prevents the amide functions to planarize (see Supporting Information).

This article will disclose the synthesis, the physicochemical properties of two original symmetrical monometallic $\mathrm{Ru}(\mathrm{II})$ bisacetylide complexes featuring this efficient platform (Chart 1). It was also found that $\mathbf{R} \mathbf{u}_{2}$ which encompasses an extended ligand aiming at further separating the hydrogen bonding sites from the 1,2-dppe crowded unit and favoring additional $\pi-\pi$ stacking interactions, and hence remotely positioned hydrogen bonding sites to afford organogels in aromatic solvents.

\section{RESULTS AND DISCUSSIONS}

Syntheses. Ru1 and Ru2 derivatives were obtained from a multistep synthetic procedure in very good yields (Scheme 1). Both compounds are air-and bench stable yellow powders. The starting compound $\mathbf{A}$ was converted into compound $\mathbf{1}$ through Sonogashira coupling (97\%). Aniline functional groups of $\mathbf{1}$ were further coupled to the gallic acid $\mathbf{C}$ presenting three dodecyl alkyl chains, with mild conditions, to afford the intermediate derivative $\mathbf{2}(91 \%)$. Finally, deprotection of the TMS group of $\mathbf{2}$ afforded $\mathbf{L}^{\mathbf{1}}$ quantitatively. A similar synthetic path was chosen for preparing $\mathbf{L}^{\mathbf{2}}$. The difference lies in the first step. Compound A was coupled to derivative $\mathbf{B}$ featuring a TMS-protected phenyl acetylene moiety to yield intermediate $\mathbf{3}$ in a quantitative manner. Note that $\mathbf{L}^{1}$ and $\mathbf{L}^{2}$ are stable for months, at room temperature and under air. Finally, $R \mathbf{u}_{1}$ and $\mathbf{R} \mathbf{u}_{2}$ complexes were obtained in $83 \%$ and $82 \%$ yields, respectively, in presence of
$\mathrm{NaPF}_{6} / \mathrm{Et}_{3} \mathrm{~N}$. $\underline{55}$ The temperature was maintained at $30^{\circ} \mathrm{C}$ to ensure proper solubility of the pro-ligands. These $\mathrm{Ru}$ complexes were characterized with ${ }^{1} \mathrm{H},{ }^{13} \mathrm{C},{ }^{31} \mathrm{P}$, FT-IR spectroscopies and HR-MS, and a full set of complementary characterizations can be found in the supporting information (spectrophotometric features). We have also probed their electrochemical behavior. Both compounds undergo a fully reversible one electron oxidation process at around $0.4 \mathrm{~V}$ vs SCE in DCM $\left(0.2 \mathrm{M}^{\mathrm{n}} \mathrm{Bu}_{4} \mathrm{NPF}_{6}\right)$ at room temperature as we expected (supporting information). Finally, we also prepared compound 5, which does not present the Ru-centered building block, in order to investigate the importance of the molecule rod-like shape. As a result, derivative 5 was obtained from the homocoupling of $\mathbf{L}^{\mathbf{2}}$ in Glaser conditions in poor yields $(17 \%)$. This low yield probably originates from the very poor solubility of $\mathbf{5}$ in common organic solvents which prevent high yield purification.

Gelation properties. The gelation properties of $\mathbf{L}^{\mathbf{2}}, \mathbf{R \mathbf { u } _ { 1 }}, \mathbf{R \mathbf { u } _ { 2 }}$ and $\mathbf{5}$ studied by the inversion method are summarized in Table 1. The pro-ligand $\mathbf{L}^{2}$ was able to form transparent gels (Figure 1) in alkane solvents such as cyclohexane, methylcyclohexane, $n$-dodecane or $n$-heptane with CGC (Critical Gelation Concentration) of $1.3 \mathrm{mg} / \mathrm{mL}$, except for methylcyclohexane $(4.0 \mathrm{mg}$ $/ \mathrm{mL}$ ). These values are similarly to those found for other organic gelators possessing an analogous structure. $\underline{54}$ As previously reported by Ziessel et al., $\frac{56}{\mathbf{L}^{1}}$ affords turbid gels in acetone only. Therefore, extending the aromatic platform with $\mathbf{L}^{2}$ has markedly improved the overall gelation ability. Interestingly, gelation abilities are annihilated with dimer compound $\mathbf{5}$ as it is not soluble in any solvents used in this study, except in $\mathrm{CHCl}_{3}$ which was used to characterize it. Concerning the complexes, $\mathbf{R} \mathbf{u}_{1}$ does not form any gels but precipitates in cyclohexane and methylcyclohexane when cooling down to room temperature. In aromatic solvents, the molecule is still soluble after cooling. On the contrary, $\mathbf{R u} 2$ derivative affords turbid gels in aromatic solvent, while in alkanes the compound is not soluble. CGCs of approximatively $30 \mathrm{mg} / \mathrm{mL}$ were obtained for benzene, o- and m-xylene, while a CGC of $20 \mathrm{mg} / \mathrm{mL}$ was measured for toluene. When compared to best organic gelator found in the literature (CGC $<1 \mathrm{mg} / \mathrm{mL}$ ) $\mathbf{R} \mathbf{u}_{2}$ gelation aptitudes are moderate but comparable to others acetylide complexes. For example, in 2011, Yang's group reported a series of bimetallic $\mathrm{Pt}(\mathrm{II})$ bis-acetylides complexes featuring an iptycene as central bulky fragment. $\underline{57}$ Unexpectedly, these molecules formed gels in alkanes with CGC ranging from 20 to $65 \mathrm{mg} / \mathrm{mL}$, However, in the present case $\mathbf{R} \mathbf{u}_{2}$ provides the first example of its kind accommodating highly sterically demanding ancillary ligand. Furthermore, comparing compounds $\mathbf{5}$ and $\mathbf{R} \mathbf{u}_{2}$ indicates that the dppe ligands play a key role in solubilizing and presumably in forming gels in aromatic solvents via probable $\pi-\pi$ stacking interactions. We have also measured the gel-to-solution transition temperatures by immersing the samples in a temperaturecontrolled bath. Transition temperature refers to the temperature at which the gel (at the CGC) starts to melt and collapses when the tube is turned upside down. Regarding pro-ligand $\mathbf{L}^{\mathbf{2}}$, transition temperatures of $55^{\circ} \mathrm{C}$ were found in n-heptane and ndodecane, whereas values of $43^{\circ} \mathrm{C}$ and $45^{\circ} \mathrm{C}$ were obtained in cyclohexane and methylcyclohexane, respectively. As a result, gels of $\mathbf{L}^{2}$ in linear alkanes are more robust. Gels of $\mathbf{R} \mathbf{u}_{2}$ in aromatic solvents display transition temperatures of $24^{\circ} \mathrm{C}$ in toluene, $31^{\circ} \mathrm{C}$ in o- and $\mathrm{m}$-xylene and $34^{\circ} \mathrm{C}$ in benzene. 

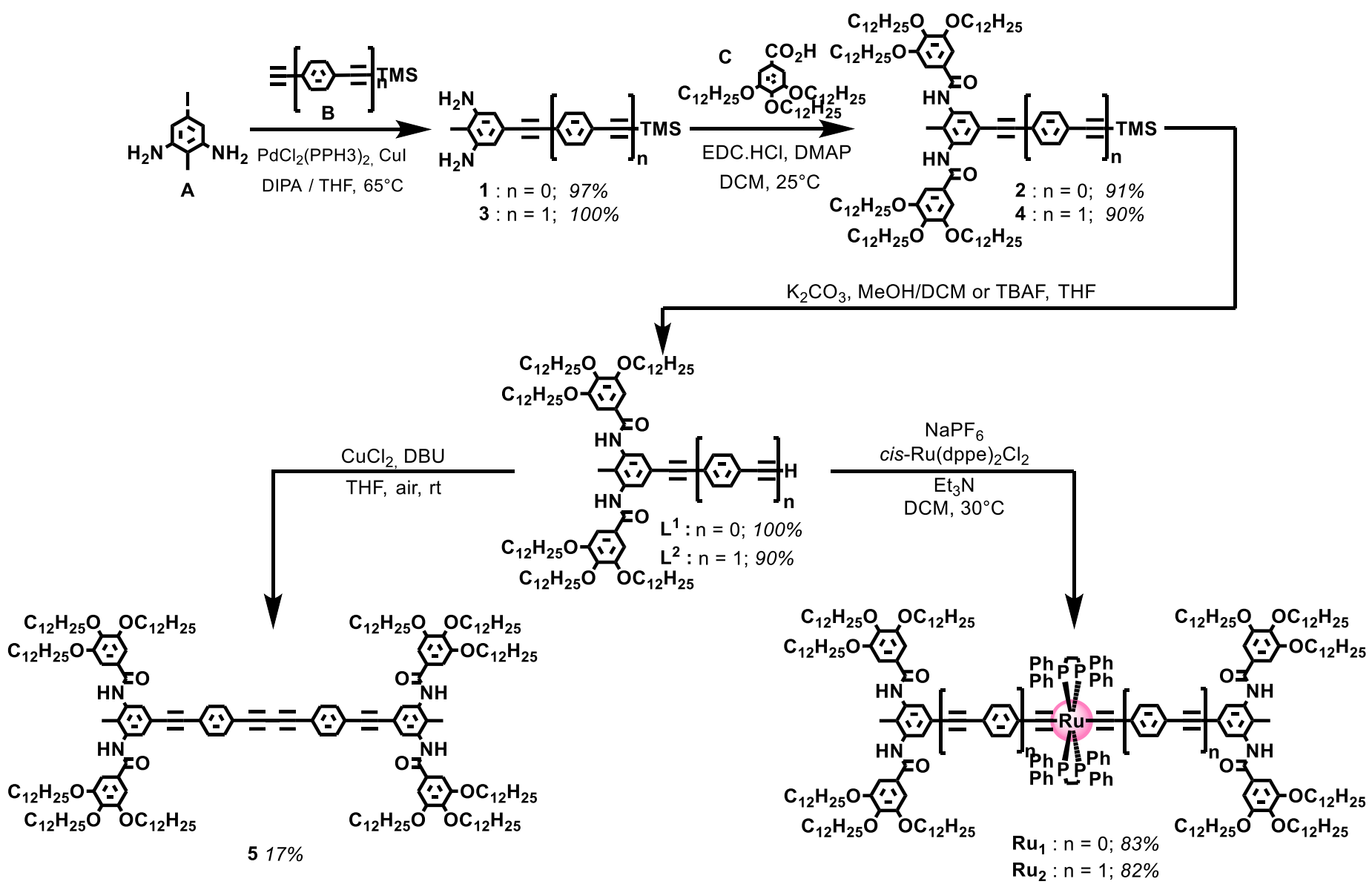

Gels of $\mathbf{R} \mathbf{u}_{2}$ and of $\mathbf{L}^{\mathbf{2}}$ are stable for at least two months in usual laboratory conditions. Even after this period of time, the gelation process can be repeated at least 5-10 times, with no loss of apparent efficiency. Note that these gels do not show any thixotropic behavior. In short, comparison between derivatives $\mathbf{L}^{2}$, 5, $\mathbf{R} \mathbf{u}_{1}$ and $\mathbf{R} \mathbf{u}_{2}$ clearly demonstrates the importance of i) the 1,2-dppe ligand which brings about some solubility and gelling ability in aromatic solvents, ii) extending the aromatic surface to favor self-assembly probably overcome the steric hindrance provided by the the dppe crown leading to more available hydrogen bonding sites, and extending the aromatic platform to offer more possibilities for the molecules to pack thanks to $\pi-\pi$ stacking interactions in particular in $\mathbf{L}^{2}$ (vide infra). Comparing $\mathbf{R} \mathbf{u}_{1}$ and $\mathbf{R} \mathbf{u}_{2}{ }^{1} \mathrm{H}$ NMR spectra in $\mathrm{CD}_{2} \mathrm{Cl}_{2}$ where no supramolecular interactions take place (see supporting information), we observed that, at room temperature, the signal assigned to aromatic protons located on the toluyl fragment experiences a drastic downfield shift from $\mathbf{R} \mathbf{u}_{1}$ to $\mathbf{R} \mathbf{u}_{2}$ (from $6.80 \mathrm{ppm}$ to $7.70 \mathrm{ppm}$ ) while the hydrogen atoms located on the gallate moieties are not affected. This shift evidences the magnetic influence of the dppe crown on these protons. Moreover, signals attributed to the methyl and the amide protons are also similarly influenced by the dppe to a minor extent. Therefore, it is reasonable to think that in Ru1 supramolecular packing via hydrogen bonding and possible $\pi-\pi$ stacking is prevented because of the bulkiness of the ancillary ligand, which in turn explains why it does not afford gels in aromatic solvent when $\mathbf{R} \mathbf{u}_{2}$ does (vide infra). This result sheds light on the importance of the ligand design and on the importance of the dppe crowding.

Figure 1. Pictures of gels from a) $\mathbf{R} \mathbf{u}_{2}$ and b) $\mathbf{L}^{2}$ derivatives. Gel to solution transition temperatures are indicated at the bottom of the figure.
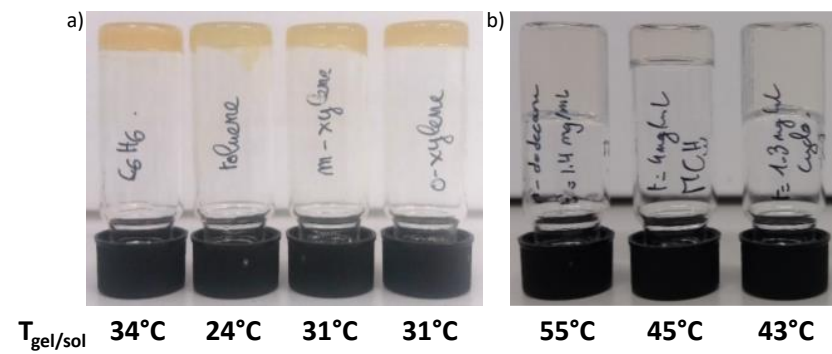
Table 1. Summary of gelation properties

\begin{tabular}{ccccccccc}
\hline & Cy & MeCy & n-heptane & n-dodecane & benzene & toluene & o-xylene & m-xylene \\
\hline L2 & G $(1.3)$ & G $(4.0)$ & G $(1.3)$ & G $(1.4)$ & NS & NS & NS \\
$\mathbf{5}$ & NS & NS & NS & NS & NS & NS & NS & NS \\
Ru1 & P & P & NS & NS & S & S & S & G (30)
\end{tabular}

Numbers in bracket represent the Critical Gelation Concentration given in $\mathrm{mg} / \mathrm{mL} . \mathrm{G}=\mathrm{Gel}, \mathrm{P}=$ Precipitate after cooling down, NS $=$ Not Soluble and $\mathrm{S}$ $=$ Soluble after cooling down (no gel).

To further support this statement, we have transposed to our complexes the model of Cavallo et al., originally developed for a better understanding of catalytic activities of organometallic complexes. $\underline{-5}$ Cavallo's calculations provide i) the percentage of buried volumes, i.e. the space occupied by a ligand in the first coordination sphere of a metal center or a putative atom, and ii) the corresponding topographic steric map of a ligand. Consequently, this map provides a quantitative description of the interaction surface between the sphere center and a substrate. Assuming that the approach of a "substrate" could be regarded as a supramolecular overlap, calculating the buried volume (steric map) at a judiciously chosen point along the molecular axis is highly relevant to apprehend the steric bulk of the dppe units and the possibilities of interactions in the present case. To achieve these calculations we first simulated $R \mathbf{u}_{1}$ and $R \mathbf{u}_{2}$ geometries with a DFT method (see supporting information for more details).Then, we used these results to calculate the Cavallo's parameters for a putative atom located at the center of the toluyl fragment along the $\mathbf{R} \mathbf{u}_{1}$ and $\mathbf{R} \mathbf{u}_{2}$ long molecular axis. In $\mathbf{R u}$, the percentage of buried volume $\left(\% \mathrm{~V}_{\text {bur }}\right)$ is calculated to be $0 \%$ reflecting a free environment available for supramolecular interactions, while in $\mathbf{R} \mathbf{u}_{1}$, at the same location, $\% \mathrm{~V}_{\text {bur }}$ is found to be $23 \%$, indicating that the dppe chelate probably precludes ligand overlapping and further supramolecular interactions.

In the next sections, we now describe our further studies on the gels and xerogels morphologies thanks to Scanning Electron Microscopy and FT-IR.

Scanning Electron Microscopy and FTIR Studies (SEM). SEM was performed to study the morphology of the corresponding xerogels (freeze-dried gels) of compounds $\mathbf{L}^{2}$ and Ru2. As observed in Figure 2, a 3D network comprising entangled fibers was obtained for xerogel of $\mathbf{L}^{2}$, with fibers diameters of $100-300 \mathrm{~nm}$. In contrast, Ru2 presents lamellar objects with width of approximatively $200-400 \mathrm{~nm}$, along with spherical particles with diameters ranging from 200 to $1000 \mathrm{~nm}$. The detection of two different type of supramolecular objects remains elusive so far. Spherical particles might be due to self-aggregation during the freeze-drying step. Nevertheless, these SEM experiments proves the capability of $\mathbf{R} \mathbf{u}_{2}$ compound to self-assemble into supramolecular ribbons. FT-IR spectrum of these xerogels displays the vibration of the amide $\mathrm{C}=\mathrm{O}$ bond at 1635 $\mathrm{cm}^{-1}$ for $\mathbf{L}^{2}$ and $1637 \mathrm{~cm}^{-1}$ for $\mathbf{R} \mathbf{u}_{2}$ (Figure 3). In addition, the $\mathrm{N}-\mathrm{H}$ vibration from the amido moieties was found at $3153 \mathrm{~cm}^{-1}$ for $\mathbf{L}^{\mathbf{2}}$ and $3230 \mathrm{~cm}^{-1}$ for $\mathbf{R} \mathbf{u}_{2}$. These values are characteristic of hydrogen-bonded molecules and are close to values found for very similar molecular skeleton..$^{54}$.

Figure 2. SEM images of xerogels of $\mathbf{L}^{\mathbf{2}}$ in cyclohexane, $\mathrm{CGC}=$ $1.3 \mathrm{mg} / \mathrm{mL}$ a) scale bar at $5 \mu \mathrm{m}$, b) scale bar at $1 \mu \mathrm{m}$. SEM images of xerogels of Ru2 in benzene, CGC $=30 \mathrm{mg} / \mathrm{mL}$ c) scale bar at $5 \mu \mathrm{m}, \mathrm{d})$ scale bar at $1 \mu \mathrm{m}$.

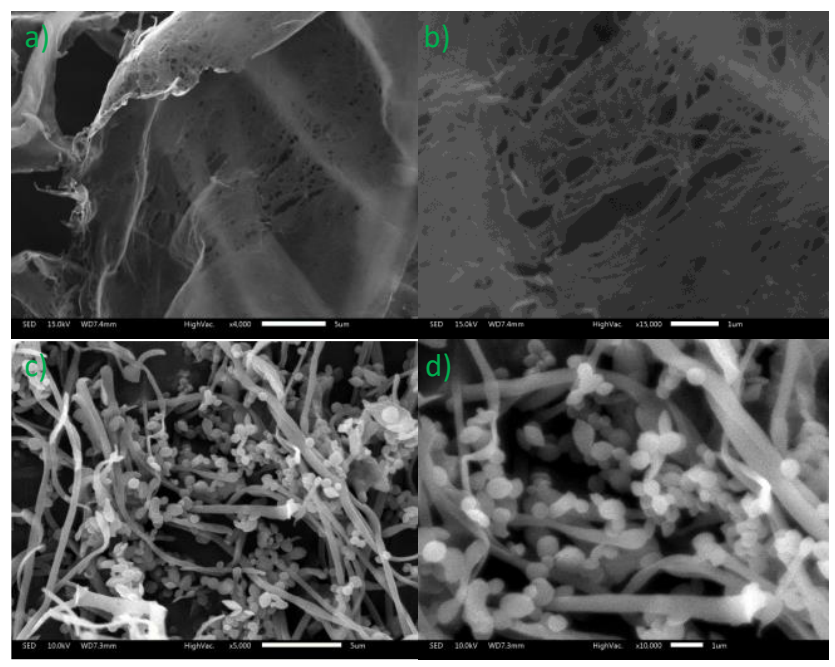

NMR studies of gelation. To get more insight into the supramolecular processes, the gel formation was monitored by ${ }^{1} \mathrm{H}$ Variable Temperature NMR (VT-NMR) studies in $\mathrm{C}_{6} \mathrm{D}_{12}$ for $\mathbf{L}^{2}$ and $\mathrm{C}_{6} \mathrm{D}_{6}$ for $\mathbf{R} \mathbf{u}_{2}$. Starting with compound $\mathbf{L}^{2}$ (see supporting information), the broad signal located at $8.3 \mathrm{ppm}$ assigned to amide groups protons experiences an downfield shift $(+0.61$ $\mathrm{ppm}$ ) as the temperature decreases from $340 \mathrm{~K}$ to $320 \mathrm{~K}$. This is a clear evidence of the involvement of the hydrogen bonds into the supramolecular process as indicated in the xerogel with IR spectroscopy. Interestingly, aromatic signals experience an upfield shift as well as the methyl protons signal located 2.00 ppm $(-0.13 \mathrm{ppm})$. Finally, the alkynyl proton exhibits no shift which leads us to think that this part of the molecule is not involved in the supramolecular packing. Additional 2D ROESY experiment performed at $325 \mathrm{~K}$ features a cross-correlation between the alkynyl proton and some protons from the aliphatic chains (Figure S29), which proves that these two group of atoms are spatially close during the self-assembly process. These observations are consistent with a head-to-tail supramolecular assembly as previously suggested by Ziessel et al on an analo- 
gous system (see supporting information). ${ }^{54}$ As far as $\mathbf{R} \mathbf{u}_{2}$ derivative is concerned, we have conducted ${ }^{1} \mathrm{H}$ and ${ }^{31} \mathrm{P}$ VT-NMR experiments in $\mathrm{C}_{6} \mathrm{D}_{6}$, at the CGC (Scheme 3). First, ${ }^{31} \mathrm{P}\left\{{ }^{1} \mathrm{H}\right\}$ experiment displays one singlet signal located at approx. $53.5 \mathrm{ppm}$ at $340 \mathrm{~K}$, a value which is characteristic of a $\mathrm{Ru}$ (II) trans-bisacetylide complex. By slowly cooling down the sample to 295 $\mathrm{K}$, the singlet signal undergoes a slight shift and vanishes because of gelation at $300 \mathrm{~K}$. This singlet signal reappears when the sample is warmed above the gelation temperature. We repeated this experiment at least four times and showed great reproducibility with no obvious degradation. Therefore, we can safely conclude that $\mathbf{R} \mathbf{u}_{2}$ is chemically stable in that temperature range, as already suggested by qualitative observations. Regarding the ${ }^{1} \mathrm{H}$ NMR spectrum, the broad singlet signal located at $7.45 \mathrm{ppm}$ and assigned to the amide protons experiences a significant downfield shift from $340 \mathrm{~K}$ to $300 \mathrm{~K}$ (+0.55 ppm). This is in line with molecules interacting trough hydrogen bonds, presumably between their amide groups, as for $\mathbf{L}^{2}$. Importantly, the singlet signal located at $2.20 \mathrm{ppm}$ (methyl protons) also experiences a downfield shift. This is in stark contrast with what was observed on ligand $\mathbf{L}^{2}$ and might suggest, at this stage, that $\mathbf{R} \mathbf{u}_{2}$ does not pack the same way as $\mathbf{L}^{2}$ does. However, the choice of solvent deeply matters in the context of supramolecular chemistry and therefore, the comparison between $\mathbf{L}^{2}$ and $\mathbf{R} \mathbf{u}_{2}$ may not be so straightforward. $\underline{59}$ Interestingly, multiplet signals due to the dppe aromatic protons does not shift with temperature indicating that the dppe is not involved in the supramolecular process, as we anticipated. Additional 2D NOESY and 2D ROESY performed at $315 \mathrm{~K}$ exhibit cross-correlations indicating several dipolar coupling between protons of the toluyl fragment, the amido groups and the fatty chains (Figure S30 \& S31). These through-space couplings support the existence of supramolecular contacts involving the acetylide ligands. Further variable temperature DOSY-NMR (Figure S23) were conducted in $\mathrm{C}_{6} \mathrm{D}_{6}$ at the CGC to measure the gel-to-solution transition temperature. The molecular diffusion coefficient reached a plateau at $32{ }^{\circ} \mathrm{C}$, meaning that the gel state was obtained. This value is in good agreement with the one measured previously (Figure 1).

To sum up, FT-IR combined to NMR and VT-NMR experiments have clearly established that hydrogen bonds are involved in the construction of the supramolecular assemblies. On one hand $\mathbf{L}^{2}$ seems to behave as reported by Ziessel et al., with molecules packing in a head-to-tail fashion and rejecting the alkynyl protons out of the structure. On the other hand, whereas $\mathbf{R} \mathbf{u}_{2}$ compound also exhibits hydrogen bonding that are central for the assembly (downfield shift of the amide proton signal), the methyl signal also experiences a downfield shift which is inconsistent with a head-to-tail supramolecular packing. Eventually, VT-NMR and 2D NOESY and 2D ROESY clearly evidences that dppe are not involved in the supramolecular process.

Small Angle X-ray Scattering (SAXS). To get a better insights into the supramolecular architectures of both gels, we performed Small Angle X-ray Scattering experiments. The X-ray scattering of the ligand $\mathbf{L}^{2}$ (Figure 4) exhibits two peaks at $0.344 \AA^{-1}$ and $0.69 \AA^{-1}$ corresponding to long-range order with a lamellar repeat distance $\boldsymbol{a}_{\mathrm{L}}$ of $18.2 \AA$ (supporting information, Figure S33). An additional broad scattering is observed at
$0.15 \AA^{-1}$ indicating a short-range order interdistance $\boldsymbol{b}_{\mathrm{L}}$ of $42 \pm 5 \AA$. This suggests a lamello-columnar organization. In this hypothesis, the columnar cross section is $\boldsymbol{S}_{\mathrm{L}}=\boldsymbol{a}_{\mathrm{L}} \boldsymbol{b}_{\mathrm{L}}=760 \AA^{2}$. These arrangements and surface are close to those of the parent system et $\mathrm{al}^{\frac{54}{4}}$ and confirms the column formation tendency observed by NMR and FTIR. Note that the orientation of the diamido backbone can be either in plane or perpendicular to the layer. However this can be clarified by noting that the aromatic volume ratio is between $25 \%$ and $30 \%$. This imposes the mean thickness of the aromatic part in the lamellar structure to be thinner than $5.5 \AA$ which is incompatible with a perpendicular orientation. The in plane orientation is compatible with observed H-bonds and the head-to-tail packing hypothesis. Thus, the hierarchical structure of the gel is consequently formed by large fibers which are made of columns with a head-to-tail packing organized in layers by means of chain interdigitation.

Figure 3. Xerogel FTIR spectrum of $\mathbf{L}^{2}$ in cyclohexane, $C G C=1.3$ $\mathrm{mg} / \mathrm{mL}$ and of $\mathbf{R} \mathbf{u}_{2}$ in benzene, $\mathrm{CGC}=30 \mathrm{mg} / \mathrm{mL}$.

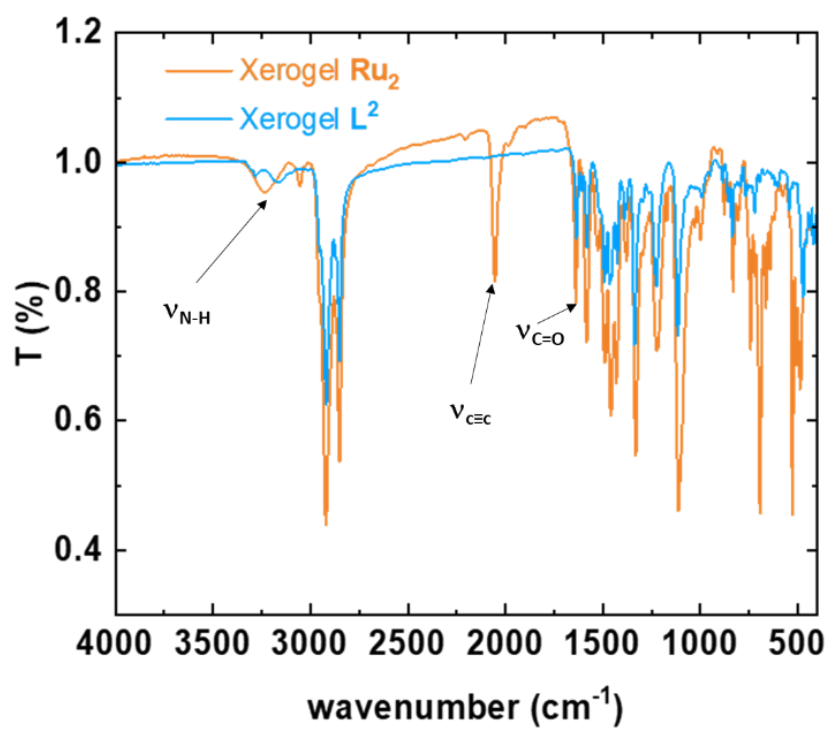

The X-ray scattering of $\mathbf{R} \mathbf{u}_{2}$ (Figure 4) exhibits a well-defined set of lamellar peaks at $0.158,0.32,0.480$ and $0.65 \AA^{-1}$ corresponding to a repeat distance $\boldsymbol{a}_{\mathrm{Ru}}$ of $39.2 \AA$. The length of the aromatic-ethenyl-Ru rigid part is about $33 \AA$. This is compatible with a perpendicular orientation to the layers. Interestingly, the amide backbone is parallel to the layer and therefore perpendicular to the mean plane containing the acetylide scaffold. In other words, $\mathbf{R} \mathbf{u}_{2}$ forms lateral intermolecular hydrogen bonds leading to layers of molecules showing a segregation between the aliphatic part and the aromatic part. Thanks to chain interdigitations, the layers assemble together affording large ribbons (Figure S33) responsible for the gelation. In particular, aromatic solvent molecules might be confined within the layers, therefore contributing to the overall solvent immobilization. Such a result echoes with the fact that the $\mathbf{R} \mathbf{u}_{2}$ gels are weak, fragile and feature moderate gel-to-sol transition temperatures. Overall, SAXS confirm that $\mathbf{L}^{\mathbf{2}}$ and $\mathbf{R} \mathbf{u}_{2}$ present different packing as already suggested by the VT-NMR experiments. 
Scheme 3. Partial ${ }^{1} H$ VT-NMR monitoring of $R_{u_{2}}$ in $C_{6} D_{6}(c=30 \mathrm{mg} / \mathrm{mL})$. Inset shows ${ }^{31} P\left\{{ }^{1} H\right\} V T-N M R$ monitoring recorded in the same conditions. Lines are used as guide for the eye. Red line $=$ amide protons, green line $=$ methyl signal and purple line $=1,2-$ dppe signals

$295 \mathrm{~K}$
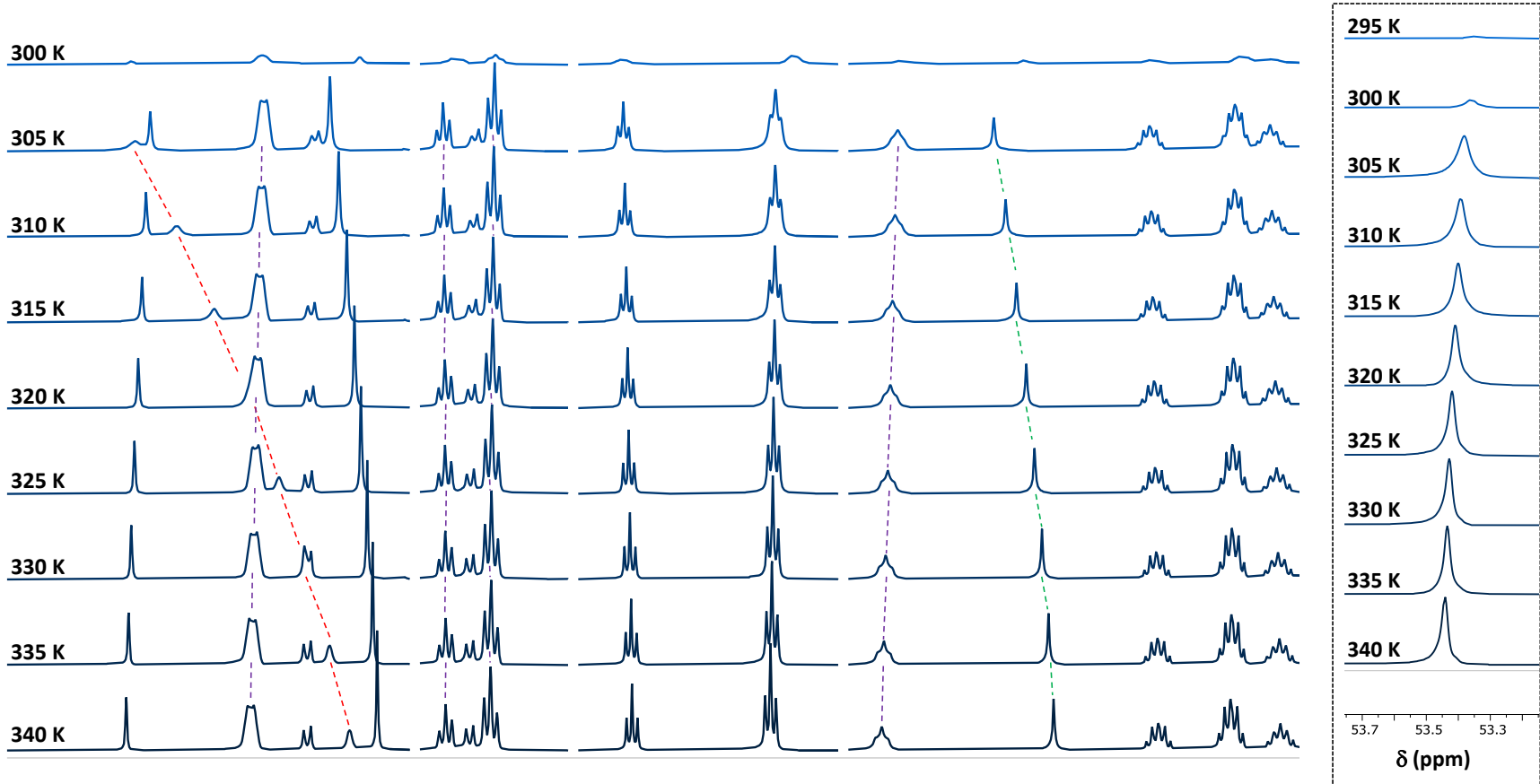

$\begin{array}{llllllllllllllllllllllllllllllllllllllll}8.2 & 8.1 & 8.0 & 7.9 & 7.8 & 7.7 & 7.6 & 7.5 & 7.4 & & 7.0 & 6.9 & 6.8 & 4.4 & 4.3 & 4.2 & 4.1 & 4.0 & 3.9 & 3.8 & 2.6 & 2.5 & 2.4 & 2.3 & 2.2 & 2.1 & 2.0 & 1.9 & 1.8 & 1.7\end{array}$ $\delta$ (ppm)

Figure 4. SAXS diffractogram of $\mathbf{L} \mathbf{2}$ and $\mathbf{R} \mathbf{u}^{2}$ collected in gels at their respective CGC. Patterns are shifted for clarity. Dotted arrows correspond to lamellar peaks. Solid line indicate lateral order within the layers.

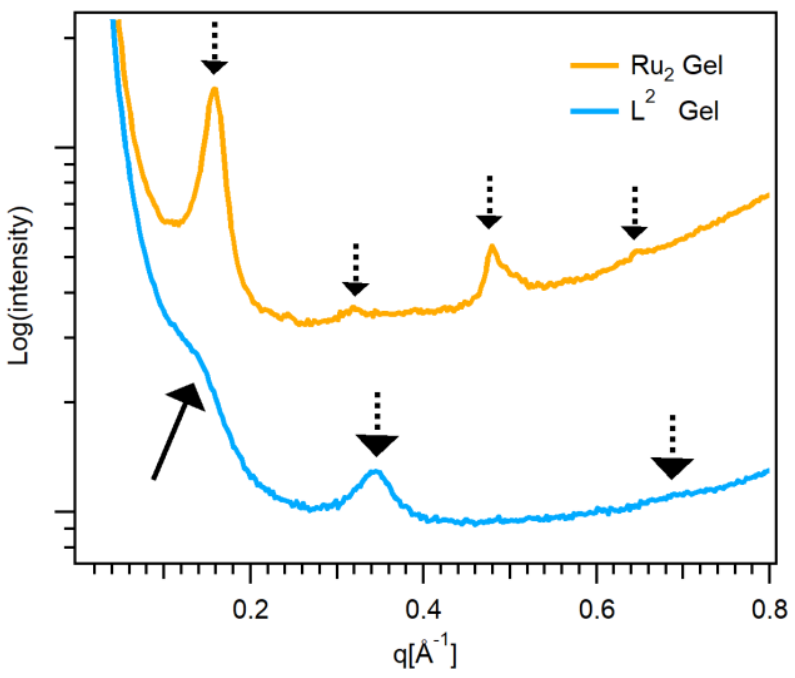

\section{CONCLUSIONS}

To conclude, we have successfully synthetized the first example of a $\mathrm{Ru}(\mathrm{II})$ bis-acetylide complex showing supramolecular capabilities. By means of a rational molecular engineering which consists i) in placing hydrogen bonding accepting/donating groups out of the molecule's long axis and ii) in extending the ligand platform in order to decrease the steric influence of the dppe crown, this complex was able to form ribbons in aromatic solvents, which in turn induced gelation of the solution. In particular, NMR, VT-NMR, FT-IR spectroscopies have evidenced that hydrogen bonds are mainly responsible for the self-organization. VT-NMR and SAXS have also suggested that both the pro-ligand and the complex self-assemble thanks to hydrogen bonding interactions. While $\mathbf{L}^{2}$ packs in a head-to-tail fashion, Ru 2 forms lateral hydrogen bonding with a segregation between the aliphatic and the aromatic parts. We are currently investigating the self-assembly mechanism, and the necessity for the complex to be symmetrical to generate supramolecular packing. We believe these results open the door to new opportunities for redox active $\mathrm{Ru}$ bis-acetylides compounds, and will encourage the development of new parent complexes featuring improved gelation efficiencies.

\section{EXPERIMENTAL SECTION}

General information. Chemicals and solvents (HPLC, spectroscopic grade) were purchased from Merck-Sigma Aldrich, Acros Organics, Alfa Aesar, Fisher Scientific and were used without any further treatment. Anhydrous (HPLC) solvents were obtained from a MBraun SPS800 drying system. Dry THF was obtained after distillation on Na/Benzophenone. Dry Diisopropylamine (DIPA), dry Triethylamine (TEA) and dry DMF were obtained from after distillation on $\mathrm{CaH}_{2}$ and kept in the dark on molecular sieves. All reactions were carried out under argon atmosphere using Schlenk techniques, unless otherwise stated. Schlenk tubes were dried under vacuum using heat-gun. TLC analyses were achieved on silica gel and bought from Fluka (silica gel matrix containing a fluorescent indicator at $254 \mathrm{~nm}$ ). Column chromatography were performed on silica gel from Acros Organics (pore size of $60 \AA$, 
particle size of $40-63 \mu \mathrm{m})$ unless otherwise stated. ${ }^{1} \mathrm{H},{ }^{13} \mathrm{C}$ and ${ }^{31} \mathrm{P}$ NMR spectra were recorded on a Bruker Avance III $400 \mathrm{MHz}$, Bruker AMX-3 $300(300 \mathrm{MHz})$ at $303 \mathrm{~K}$. Relevant compounds were also characterized by $2 \mathrm{D}$ NMR using HSQC/HMQC, COSY ${ }^{1} \mathrm{H}-{ }^{1} \mathrm{H}$, HMBC sequences. VT-NMR were recorded on a Bruker Ascend $500 \mathrm{MHz}$ Av III HD. Deuterated solvents were bought from Euriso-top. Infrared spectra $(\mathrm{KBr})$ were acquired on a spectrophotometer FTIR BRUKER EQUINOX 55. HR-MS spectra were obtained from the Centre Régional de Mesures Physiques de l'Ouest (CRMPO). Intermediate A was obtained through an adapted procedure from the literature (see supporting information). Precursors $\mathbf{B}$ and $\mathbf{C}$ were synthetized as reported in the literature (see supporting information for a reference).

Electrochemical measurements. Electrochemical studies were carried out under argon using an Eco Chemie Autolab PGSTAT 30 potentiostat $\left(\mathrm{CH}_{2} \mathrm{Cl}_{2}, 0.2 \mathrm{M} \mathrm{Bu} 4 \mathrm{NPF}_{6}\right)$, the working electrode was a Carbon disk and decamethylferrocene the internal reference.

Scanning Electron Microscopy (SEM). Metallization by $\mathrm{Au} / \mathrm{Pd}$. Scanning Electron Microscopy (SEM) of xerogels were evaluated using the JEOL IT 300 Scanning Electron Microscope. Samples were collected and deposited on a Teflon plot. Each sample was examined using a voltage of 5 or $10 \mathrm{kV}$. Images were analyzed by SMileView software.

Small Angle X-Ray Scattering (SAXS). Organogel and xerogel samples were prepared into capillaries. SAXS experiments were performed using X-ray patterns collected with a Pilatus 300k (Dectris, Grenoble, France) mounted on a microsource X-ray generator GeniX 3D (Xenocs, Sassenage, France) operating at 30 watts. The monochromatics CuKaradiation is of $\lambda=1.541 \AA$. The diffraction patterns were therefore recorded for reciprocal spacing $\mathrm{q}=4 \pi * \sin \theta / \lambda$ in a range of repetitive distances from $0.015 \AA-1(418 \AA)$ and $1.77 \AA-1(8 \AA)$. Images were transformed to graphics using the software program Fit2D (ESRF).

Syntheses.

Compound 1. A dried Schlenk tube was charged with compound A (0.200 g, $0.8 \mathrm{mmol}, 1$ eq.), $\mathrm{PdCl}_{2}\left(\mathrm{PPh}_{3}\right)_{2}(0.085 \mathrm{~g}, 5 \mathrm{~mol} \%)$ and $\mathrm{CuI}$ $(0.023 \mathrm{~g}, 5 \mathrm{~mol} \%)$ under argon flow. Then, distillated $\mathrm{Et}_{3} \mathrm{~N}(12 \mathrm{~mL})$ was added followed by dry THF $(12 \mathrm{~mL})$. To this mixture was added excess of neat TMSA (500 $\mu \mathrm{L}, 5 \mathrm{mmol}, 2$ eq.) and the mixture was refluxed for $24 \mathrm{~h}$. The crude was allowed to cool to room temperature and was diluted with aq. $\mathrm{NH}_{4} \mathrm{Cl}$ saturated solution. The aqueous layer was extracted with EtOAc several times. The organics were dried over $\mathrm{Na}_{2} \mathrm{SO}_{4}$, filtered and the solvents were removed. The crude mixture was purified by flash column chromatography (silica, DCM/EtOH 0 to $1.2 \%$ ) to afford $512 \mathrm{mg}$ of the expected compound $\mathbf{1}$ (yield 97\%). ${ }^{1} \mathrm{H}$ NMR (400 MHz, $\left.\mathrm{CDCl}_{3}\right): \delta=6.33\left(\mathrm{~s}, 2 \mathrm{H}_{\mathrm{Ar}}\right), 3.53$ (broad singlet, $4 \mathrm{H}_{\text {amine }}$ ), 1.95 (s, $\left.3 \mathrm{H}_{\text {methyl }}\right), 0.22$ (s, 9H $\left.\mathrm{H}_{\mathrm{TMS}}\right) ;{ }^{13} \mathrm{C} \mathrm{NMR}(100 \mathrm{MHz}$ $\left.\mathrm{CDCl}_{3}\right): \delta=144.84,120.92,110.25,108.47,105.74,92.08,10.31,0.02$ (C $\mathrm{C}_{\text {TMS }}$ ). HRMS (ESI): $\mathrm{m} / \mathrm{z} 219.1312$ calcd for $\mathrm{C}_{12} \mathrm{H}_{19} \mathrm{~N}_{2} \mathrm{Si}\left[M+H^{+}\right]$; found: 219.1312 .

Compound $\mathbf{R u}_{1}$. A dried Schlenk flask was charged with cis$\mathrm{RuCl}_{2}$ (dppe) $)_{2}\left(0.050 \mathrm{~g}, 0.05 \mathrm{mmol}, 1\right.$ eq.), compound $\mathbf{L}^{1}(0.165 \mathrm{~g}, 0.11$ mmol, 2.2 eq. $)$ and $\mathrm{NaPF}_{6}(0.052 \mathrm{~g}, 0.31 \mathrm{mmol}, 6 \mathrm{eq}$.) under argon flow. The tube was evacuated (30 min) and backfilled with argon. Then, a solution of distillated $\mathrm{Et}_{3} \mathrm{~N}$ ( $417 \mu \mathrm{L}, 3 \mathrm{mmol}, 60$ eq.) in dry DCM (16 $\mathrm{mL}$ ) was added with a ssyringe., The reaction mixture was stirred at $30^{\circ} \mathrm{C}$ during 4 days. ${ }^{31} \mathrm{P}\left\{{ }^{1} \mathrm{H}\right\}$ (no lock procedure) NMR monitoring of the reaction indicated only one singlet signal at around $53 \mathrm{ppm}$. The reaction mixture was diluted with DCM $(10 \mathrm{~mL})$, washed with water $(3 \times 10 \mathrm{~mL})$. The organic layer was collected dried on $\mathrm{Na}_{2} \mathrm{SO}_{4}$, filtered and the solvent was removed. The crude was taken up in $10 \mathrm{~mL}$ DCM and precipitated by dropwise addition of $10 \mathrm{~mL}$ of $\mathrm{MeOH}$. The yellow precipitate was filtered-off under air and dried to afford the corresponding $\mathbf{R} \mathbf{u}_{1}$ compound ( $\mathrm{m}=0.164 \mathrm{~g}$, yield $\left.83 \%\right)$. ${ }^{1} \mathrm{H}$ NMR (400 $\left.\mathrm{MHz}, \mathrm{CD}_{2} \mathrm{Cl}_{2}\right): \delta=7.51\left(\mathrm{~m}, 20 \mathrm{H} \mathrm{H}_{\text {dppe }}+\mathrm{H}_{\text {amide }}\right), 7.49\left(\mathrm{t}, 16 \mathrm{H},{ }^{3} J_{H H}=\right.$ $\left.7.6 \mathrm{~Hz}, \mathrm{H}_{\mathrm{dppe}}\right), 7.13-7.17\left(\mathrm{~m}, 16 \mathrm{H}, \mathrm{H}_{\mathrm{Ar}}+\mathrm{H}_{\mathrm{dppe}}\right), 6.81\left(\mathrm{~s}, 4 \mathrm{H}, \mathrm{H}_{\mathrm{tol}}\right), 4.08$ (dt, $24 \mathrm{H},{ }^{3} J_{H H}=6.5 \mathrm{~Hz}, \mathrm{H}_{\text {alkyl }}$ ), 2.66 (br. s, $8 \mathrm{H}, \mathrm{CH} 2_{\text {dppe) }}, 2.17$ (s, $6 \mathrm{H}$, $\left.\mathrm{H}_{\mathrm{Me}}\right), 1.88-1.71$ (m, 28H, $\left.\mathrm{H}_{\text {chain }}\right), 1.54$ (m, $\left.\mathrm{H}_{\text {chain }}\right), 1.28$ (br. s, $205 \mathrm{H}$, $\left.\mathrm{H}_{\text {chain }}\right), 0.88\left(\mathrm{~m}, 36 \mathrm{H}, \mathrm{Me}_{\text {Chain }}\right) ;{ }^{13} \mathrm{C} \mathrm{NMR}\left(75 \mathrm{MHz}, \mathrm{CD}_{2} \mathrm{Cl}_{2}\right): \delta=$ $166.09,153.75,141.68,141.68,137.46$ (quint, $J=10.2 \mathrm{~Hz}$ ), 136.27, $134.61,130.43,129.09,127.57,125.24,123.13,116.07,73.93,69.82$, $32.39,31.85\left(\mathrm{~m},{ }^{1} \mathrm{~J}_{\mathrm{P}, \mathrm{C}}+{ }^{3} \mathrm{~J}_{\mathrm{P}, \mathrm{C}}=24 \mathrm{~Hz}, \mathrm{P}\left(\mathrm{CH}_{2}\right)_{2} \mathrm{P}\right), 30.81,30.21-29.81$ (br. m.), 26.59, 23.14, 23.12, 14.32, 13.13. ${ }^{31} \mathrm{P}\left\{{ }^{1} \mathrm{H}\right\} \mathrm{NMR}(162 \mathrm{MHz}$, $\left.\mathrm{CD}_{2} \mathrm{Cl}_{2}\right): \delta=53.17$. HRMS (ESI): $\mathrm{m} / \mathrm{z} 3814.62505$ calcd for $\mathrm{C}_{242} \mathrm{H}_{370} \mathrm{~N}_{4} \mathrm{O}_{16} \mathrm{P}_{4}{ }^{102} \mathrm{Ru}\left[M^{+}\right]$; found 3814.6298. IR $\left(\mathrm{cm}^{-1}\right): 3255\left(v_{\mathrm{N}-\mathrm{H}}\right)$, 2912, $2851\left(v_{\mathrm{C}-\mathrm{H}}\right), 2051\left(v_{\mathrm{C}=\mathrm{C}}\right), 1639\left(v_{\mathrm{C}=\mathrm{O}}\right), 1582\left(v_{\mathrm{C}=\mathrm{C}}\right) . \lambda_{\max }$ (solvent, ع): $338 \mathrm{~nm}\left(\mathrm{DCM}, 38000 \mathrm{~L} \mathrm{~mol}^{-1} \mathrm{~cm}^{-1}\right)$.

Compound 3.

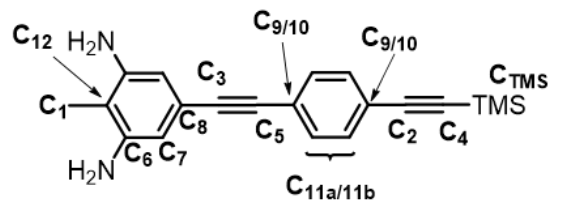

A dried Schlenk tube was charged with compound A $(0.200 \mathrm{~g}, 0.8$ mmol, 1 eq.), compound $\mathbf{B}(0.208 \mathrm{~g}, 1.0 \mathrm{mmol}, 1.3$ eq. $), \mathrm{PdCl}_{2}\left(\mathrm{PPh}_{3}\right)_{2}$ $(0.028 \mathrm{~g}, 5 \mathrm{~mol} \%)$ and $\mathrm{CuI}(0.007 \mathrm{~g}, 5 \mathrm{~mol} \%)$ under argon flow. Dry THF $(4 \mathrm{~mL})$ and dry DIPA $(4 \mathrm{~mL})$ were added by syringe. The mixture darkened. The dark solution was refluxed $\left(65^{\circ} \mathrm{C}\right) 24 \mathrm{hrs}$. The crude was diluted with saturated aq. $\mathrm{NH}_{4} \mathrm{Cl}$ solution and extracted with $\mathrm{Et}_{2} \mathrm{O}$ several times. The organics were combined, dried over $\mathrm{MgSO}_{4}$, filtered and the solvents were removed. Purification by column chromatography (silica, DCM/EtOAc mixture) afforded the desired compound $3(\mathrm{~m}=0.230 \mathrm{~g}$, yield $90 \%) .{ }^{1} \mathrm{H}$ NMR $\left(400 \mathrm{MHz}, \mathrm{CDCl}_{3}\right): \delta$ $=7.42\left(\mathrm{~s}, 4 \mathrm{H}, \mathrm{H}_{10 / 11}\right), 6.38\left(\mathrm{~s}, 2 \mathrm{H}, \mathrm{H}_{7}\right), 3.59$ (broad singlet, $\left.4 \mathrm{H}, \mathrm{H}_{\text {amine }}\right)$, 1.97 (s, 3H, H $\left.\mathrm{H}_{1}\right), 0.26$ (s, 9H, $\left.\mathrm{H}_{\mathrm{TMS}}\right) ;{ }^{13} \mathrm{C} \mathrm{NMR}\left(100 \mathrm{MHz}, \mathrm{CDCl}_{3}\right): \delta=$ $145.09\left(\mathrm{C}_{12}\right), 131.78\left(\mathrm{C}_{11 \mathrm{~b}}\right), 131.28\left(\mathrm{C}_{11 \mathrm{a}}\right), 123.69\left(\mathrm{C}_{10}\right), 122.47\left(\mathrm{C}_{9}\right)$, $120.77\left(\mathrm{C}_{8}\right), 109.73\left(\mathrm{C}_{7}\right), 108.35\left(\mathrm{C}_{6}\right), 104.73\left(\mathrm{C}_{5}\right), 95.98\left(\mathrm{C}_{4}\right), 91.99$ $\left(\mathrm{C}_{3}\right), 87.35\left(\mathrm{C}_{2}\right), 10.33\left(\mathrm{C}_{1}\right),-0.09$ ( $\left.\mathrm{C}_{\text {TMS }}\right)$. HRMS (ESI): $m / z, 341.1445$ calcd for $\mathrm{C}_{20} \mathrm{H}_{22} \mathrm{~N}_{2} \mathrm{Si} \mathrm{Na}\left[M+N a^{+}\right]$; found: 341.1445.

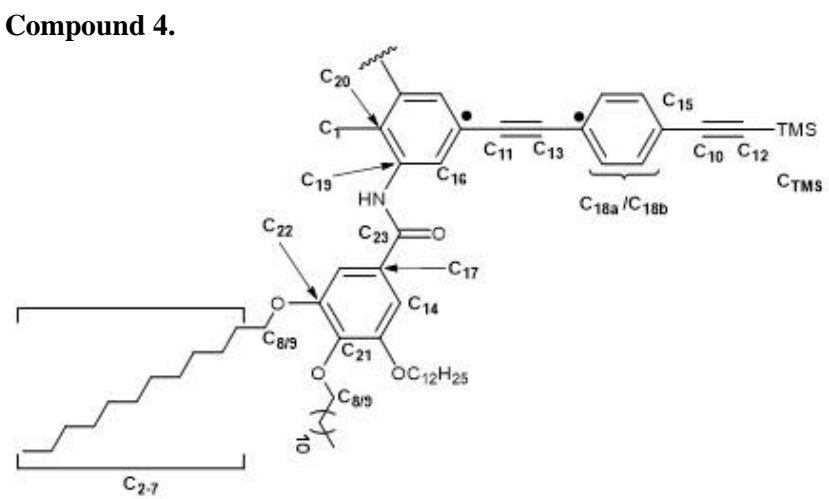

A dried Schlenk tube was charged with compound $3(0.164 \mathrm{~g}, 0.52$ mmol, 1 eq.), compound $\mathbf{C}(0.870 \mathrm{~g}, 1.3 \mathrm{mmol}, 2.5$ eq.), EDC. $\mathrm{HCl}$ (0.248 g, $1.3 \mathrm{mmol}, 2.5$ eq.) and DMAP $(0.157 \mathrm{~g}, 1.3 \mathrm{mmol}, 2.5$ eq. $)$ under argon flow. Dry DCM $(3.5 \mathrm{~mL})$ was added via syringe. The brownish solution was then warmed at $30^{\circ} \mathrm{C}$ over 3 days. The crude was diluted with DCM, washed with water. The organic phase was collected, dried on $\mathrm{Na}_{2} \mathrm{SO}_{4}$, filtered. The solvent was removed. Purification by column chromatography (silica, DCM/EtOAc $100 \% / 0 \%$ to $98 \% / 2 \%)$ afforded the desired compound $(\mathrm{m}=0.671 \mathrm{~g}$, yield $80 \%)$. ${ }^{1} \mathrm{H} \mathrm{NMR}\left(400 \mathrm{MHz}, \mathrm{CDCl}_{3}\right): \delta=7.74\left(\mathrm{~s}, 2 \mathrm{H}_{16}\right), 7.65$ (br. s, 2H, $\mathrm{H}_{\text {amine }}$ ), 7.42 (s, 4H, $\left.\mathrm{H}_{18}\right), 7.09$ (s, 4H, $\left.\mathrm{H}_{14}\right), 4.04\left(\mathrm{~m}, 12 \mathrm{H}, \mathrm{H}_{8}\right), 2.25$ $\left(\mathrm{s}, 3 \mathrm{H}, \mathrm{H}_{1}\right), 1.83\left(\mathrm{~m}, 12 \mathrm{H}, \mathrm{H}_{2-7}\right), 1.43-1.23\left(\mathrm{~m}, 108 \mathrm{H}, \mathrm{H}_{2-7}\right), 0.88(\mathrm{~m}$, $\left.18 \mathrm{H}, \mathrm{H}_{2-7}\right), 0.25$ (s, 9H, $\left.\mathrm{H}_{\mathrm{TMS}}\right) ;{ }^{13} \mathrm{C}$ NMR $\left(75 \mathrm{MHz}, \mathrm{CDCl}_{3}\right): \delta=165.94$ $\left(\mathrm{C}_{23}\right), 153.28\left(\mathrm{C}_{22}\right), 141.77\left(\mathrm{C}_{21}\right), 139.67\left(\mathrm{C}_{20}\right), 136.43\left(\mathrm{C}_{19}\right), 131.83$ $\left(\mathrm{C}_{18 \mathrm{~b}}\right), 131.32\left(\mathrm{C}_{18 \mathrm{a}}\right), 128.99\left(\mathrm{C}_{17}\right), 125.42\left(\mathrm{C}_{16}\right), 123.05\left(\mathrm{C}_{15}\right), 123.00$ $\left(\mathrm{C}_{14}\right), 106.02\left(\mathrm{C}_{13}\right), 104.61\left(\mathrm{C}_{12}\right), 96.25\left(\mathrm{C}_{11}\right), 90.45\left(\mathrm{C}_{10}\right), 89.45\left(\mathrm{C}_{8 / 9}\right)$, $73.59\left(\mathrm{C}_{8 / 9}\right), 69.44\left(\mathrm{C}_{7}\right), 31.92\left(\mathrm{C}_{6}\right), 30.36\left(\mathrm{C}_{5}\right), 29.75\left(\mathrm{C}_{5}\right), 29.71\left(\mathrm{C}_{5}\right)$, $29.66\left(C_{5}\right), 29.61\left(C_{5}\right), 29.44\left(C_{5}\right), 29.36\left(C_{5}\right), 26.11\left(C_{4}\right), 22.68\left(C_{3}\right)$, $14.09\left(\mathrm{C}_{2}\right), 13.36\left(\mathrm{C}_{1}\right),-0.10$ ( $\left.\mathrm{C}_{\text {TMS }}\right)$. HRMS (MALDI-DCTB): $\mathrm{m} / \mathrm{z}$ 1654.29317 calcd for $\mathrm{C}_{106} \mathrm{H}_{174} \mathrm{~N}_{2} \mathrm{O}_{8} \mathrm{SiNa}\left[\mathrm{M}+\mathrm{Na}^{+}\right.$]; found: 1654.3060 . IR $\left(\mathrm{cm}^{-1}\right): 3177\left(v_{\mathrm{N}-\mathrm{H}}\right), 2917\left(\mathrm{v}_{\mathrm{C}-\mathrm{H}}\right), 2850\left(\mathrm{v}_{\mathrm{C}-\mathrm{H}}\right), 2109\left(\mathrm{v}_{\mathrm{C} \equiv \mathrm{C}}\right), 1635$ $\left(v_{\mathrm{C}=0}\right), 1580\left(v_{\mathrm{C}=\mathrm{C}}\right)$. 
Compound $\mathrm{L}^{2}$.

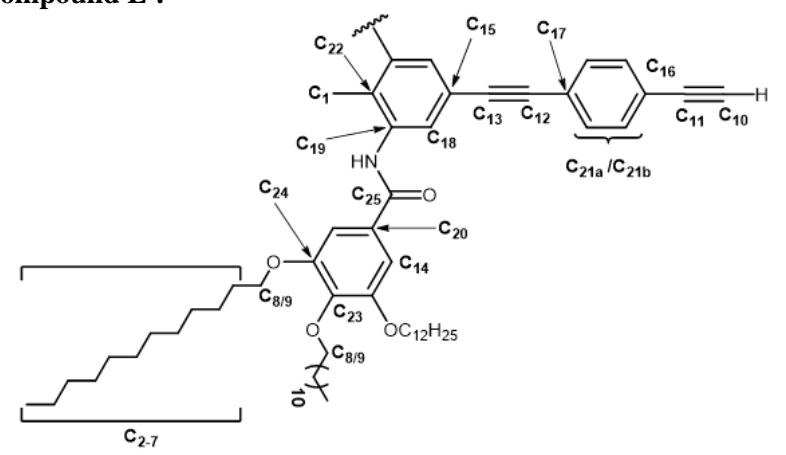

A round bottom flask equipped with a magnetic stirring bar was charged with compound 4 ( $0.671 \mathrm{~g}, 0.41 \mathrm{mmol}, 1$ eq. $)$. The compound was dissolved in a $1 / 1(\mathrm{v} / \mathrm{v})$ of DCM and $\mathrm{MeOH}$ (total volume of 30 $\mathrm{mL})$ at room temperature. Then, $\mathrm{K}_{2} \mathrm{CO}_{3}(2.552 \mathrm{~g}, 18.5 \mathrm{mmol}, 45$ eq. $)$ was added and the suspension was stirred 4-5 hrs. The mixture was partitioned between water and DCM. The aqueous layer was extracted several times with DCM. The organic phase was dried on $\mathrm{MgSO}_{4}$, filtered and the solvents were removed to afford a light yellowish powder with enough purity to be used for the next step $(0.635 \mathrm{~g}$, yield 99\%). ${ }^{1} \mathrm{H}$ NMR $\left(300 \mathrm{MHz}, \mathrm{CDCl}_{3}\right): \delta=7.98$ (s, 2H, $\mathrm{H}_{\text {amide }}$ ), 7.59 (s, $\left.2 \mathrm{H}, \mathrm{H}_{18}\right), 7.41\left(\mathrm{~d}, 2 \mathrm{H},{ }^{3} J_{H H}=8.2 \mathrm{~Hz}, \mathrm{H}_{21}\right), 7.33\left(\mathrm{~d}, 2 \mathrm{H},{ }^{3} J_{H H}=8.2 \mathrm{~Hz}\right.$, $\left.\mathrm{H}_{21}\right), 7.14$ (s, 4H, $\left.\mathrm{H}_{14}\right), 4.02\left(\mathrm{~m}, 12 \mathrm{H}, \mathrm{H}_{8 / 9}\right), 3.15$ (s, 1H, $\left.\mathrm{H}_{\text {alkyne }}\right), 2.17$ $\left(\mathrm{s}, 3 \mathrm{H}, \mathrm{H}_{1}\right), 1.80\left(\mathrm{~m}, 12 \mathrm{H}, \mathrm{H}_{6}\right), 1.47-1.27\left(\mathrm{~m}, 108 \mathrm{H}, \mathrm{H}_{4 / 5}\right), 0.88(\mathrm{~m}, 18 \mathrm{H}$, $\left.\mathrm{H}_{2}\right) ;{ }^{13} \mathrm{C} \mathrm{NMR}\left(75 \mathrm{MHz}, \mathrm{CDCl}_{3}\right): \delta=165.96\left(\mathrm{C}_{25}\right), 153.26\left(\mathrm{C}_{24}\right), 141.70$ $\left(\mathrm{C}_{23}\right), 136.40\left(\mathrm{C}_{22}\right), 131.99\left(\mathrm{C}_{21 \mathrm{~b}}\right), 131.39\left(\mathrm{C}_{21 \mathrm{a}}\right), 128.94\left(\mathrm{C}_{20}\right), 127.69$ $\left(\mathrm{C}_{19}\right), 125.51\left(\mathrm{C}_{18}\right), 123.45\left(\mathrm{C}_{17}\right), 121.93\left(\mathrm{C}_{16}\right), 121.08\left(\mathrm{C}_{15}\right), 105.96$ $\left(\mathrm{C}_{14}\right), 90.51\left(\mathrm{C}_{13}\right), 89.23\left(\mathrm{C}_{12}\right), 83.20\left(\mathrm{C}_{11}\right), 78.88\left(\mathrm{C}_{10}\right), 73.57\left(\mathrm{C}_{9}\right)$, $69.40\left(\mathrm{C}_{8}\right), 31.92\left(\mathrm{C}_{7}\right), 30.36\left(\mathrm{C}_{6}\right), 29.76\left(\mathrm{C}_{5}\right), 29.66\left(\mathrm{C}_{5}\right), 29.45\left(\mathrm{C}_{5}\right)$, $29.37\left(\mathrm{C}_{5}\right), 29.36\left(\mathrm{C}_{5}\right), 26.12\left(\mathrm{C}_{4}\right), 22.68\left(\mathrm{C}_{3}\right), 14.10\left(\mathrm{C}_{2}\right), 13.38\left(\mathrm{C}_{1}\right)$. HRMS (ESI): $\mathrm{m} / \mathrm{z} 1582.2536$ calcd for $\mathrm{C}_{103} \mathrm{H}_{166} \mathrm{~N}_{2} \mathrm{O}_{8} \mathrm{Na}\left[\mathrm{M}+\mathrm{Na}^{+}\right]$; found: 1582.2543. IR $\left(\mathrm{cm}^{-1}\right): 3442\left(v_{\mathrm{N}-\mathrm{H}}\right), 3288\left(v_{\mathrm{CC}-\mathrm{H}}\right),\left(2916\left(v_{\mathrm{C}-\mathrm{H}}\right)\right.$, $2852\left(v_{\mathrm{C}-\mathrm{H}}\right), 2107\left(v_{\mathrm{C}=\mathrm{C}}\right), 1635\left(v_{\mathrm{C}=\mathrm{O}}\right), 1583\left(v_{\mathrm{C}=\mathrm{C}}\right)$.

Compound 5. A round bottom flask equipped with a magnetic stirring bar was charged with compound $\mathbf{L}^{2}(0.448 \mathrm{~g}, 1 \mathrm{mmol}, 1 \mathrm{eq}$.), anhydrous $\mathrm{CuCl}_{2}(0.004 \mathrm{~g}, 0.0287 \mathrm{mmol} 0.1$ eq.) and THF (6 mL). Neat DBU was added dropwise $(0.051 \mathrm{~mL}, 0.34 \mathrm{mmol}, 1.2$ eq.). The mixture was refluxed over 1 day with no precaution to remove air. The reaction mixture was taken to dryness. Purification by column chromatography (Florosil ${ }^{2}, \mathrm{PE} / \mathrm{CHCl}_{3}\left(9 / 1, \mathrm{v} / \mathrm{v}\right.$ ) to $\mathrm{CHCl}_{3}$ ) followed by precipitation in a mixture of $\mathrm{CHCl}_{3}$ and $\mathrm{MeOH}$ afforded the pure compound $5(\mathrm{~m}=$ $0.150 \mathrm{~g}$, yield $17 \%) .{ }^{1} \mathrm{H}$ NMR $\left(400 \mathrm{MHz}, \mathrm{CDCl}_{3}\right): \delta=7.90(\mathrm{~s}, 4 \mathrm{H}$, $\mathrm{H}_{\text {amide }}$ ), 7.64 (s, $\left.4 \mathrm{H}, \mathrm{H}_{\text {Ar tol }}\right), 7.44$ (d, $4 \mathrm{H},{ }^{3} J_{H H}=8.3 \mathrm{~Hz}, \mathrm{H}_{\text {Ar acetylene), }} 7.37$ (d, $4 \mathrm{H},{ }^{3} J_{H H}=8.3 \mathrm{~Hz}, \mathrm{H}_{\mathrm{Ar}}$ acetylene $), 7.12\left(\mathrm{~s}, 8 \mathrm{H}, \mathrm{H}_{\mathrm{Ar} \text { side }}\right), 4.02(\mathrm{~m}, 24 \mathrm{H}$, Homethylene), 2.20 (s, 6H, HMethyl), 1.81 (m, 24H, $\left.\mathrm{H}_{\text {chain}}\right), 1.47-1.26$ (m, $\left.216 \mathrm{H}, \mathrm{H}_{\text {chain }}\right), 0.88\left(\mathrm{~m}, 36 \mathrm{H}, \mathrm{H}_{\text {chain }}\right) ;{ }^{13} \mathrm{C} \mathrm{NMR}\left(75 \mathrm{MHz}, \mathrm{CDCl}_{3}\right): \delta=$ $166.07,153.24,141.73,136.40,132.32,131.48,128.91,128.13$, $125.83,123.90,121.45,121.05,106.06,91.28,89.35,82.01,75.72$, $73.56,69.41,31.82,30.38,29.76,29.67,29.47,29.37,26.13,22.68$, 14.08, 13.36. HRMS (ESI): $\mathrm{m} / z 3139.5024$ calcd for $\mathrm{C}_{206} \mathrm{H}_{330} \mathrm{~N}_{4} \mathrm{O}_{16} \mathrm{Na}$ $\left[M+\mathrm{Na}^{+}\right]$; found: 3139.5007 . IR $\left(\mathrm{cm}^{-1}\right): 3181\left(v_{\mathrm{N}-\mathrm{H}}\right), 2916\left(\mathrm{v}_{\mathrm{C}-\mathrm{H}}\right), 2054$ $\left(v_{\mathrm{C}-\mathrm{H}}\right), 1636\left(\mathrm{v}_{\mathrm{C}=\mathrm{O}}\right), 1583\left(\mathrm{v}_{\mathrm{C}=\mathrm{C}}\right)$.

Compound $\mathbf{R} \mathbf{u}_{2}$. A dried Schlenk flask was charged with cis$\mathrm{RuCl}_{2}$ (dppe) 2 (0.121 g, 0.13 mmol, 1 eq.), compound $\mathbf{L}^{2}$ (0.400 g, 0.26 mmol, 2.05 eq.) and $\mathrm{NaPF}_{6}(0.122 \mathrm{~g}, 0.73 \mathrm{mmol}, 5.8$ eq.) under argon flow. The tube was evacuated and backfilled with argon. Then, a solution of distillated $\mathrm{Et}_{3} \mathrm{~N}$ in dry DCM $(16 \mathrm{~mL})$ was added. Finally, the reaction mixture was warmed at $30^{\circ} \mathrm{C}$ during 4 days. ${ }^{31} \mathrm{P}\left\{{ }^{1} \mathrm{H}\right\}$ (no lock procedure) NMR monitoring indicated only one singlet signal at $52.8 \mathrm{ppm}$. The reaction was stopped by adding $20 \mathrm{~mL}$ of $\mathrm{MeOH}$ over $20 \mathrm{~min}$. The compound was filtered-off. The powder was taken up in DCM $(20 \mathrm{~mL})$ and precipitate with $\mathrm{MeOH}(8 \mathrm{~mL})$ to afford compound $\mathbf{R} \mathbf{u}_{2}$ pure as a yellow powder $(\mathrm{m}=0.412 \mathrm{~g}$, yield $82 \%)$. ${ }^{1} \mathrm{H}$ NMR $(400$
$\left.\mathrm{MHz}, \mathrm{CD}_{2} \mathrm{Cl}_{2}\right): \delta=7.74\left(\mathrm{~s}, 4 \mathrm{H}, \mathrm{H}_{\text {amide }}\right), 7.73\left(\mathrm{~s}, 4 \mathrm{H}, \mathrm{H}_{\mathrm{tol}}\right), 7.49(\mathrm{~m}, 16 \mathrm{H}$, $\left.\mathrm{H}_{\mathrm{dppe}}\right), 7.30\left(\mathrm{~d}, 4 \mathrm{H},{ }^{3} J_{H H}=8.3 \mathrm{~Hz}, \mathrm{H}_{\text {Ar acetylene }}\right), 7.20\left(\mathrm{~s}, 8 \mathrm{H},{ }^{3} J_{H H}=7.5\right.$ $\left.\mathrm{Hz}, \mathrm{H}_{\mathrm{dppe}}\right), 6.97\left(\mathrm{t}, 16 \mathrm{H},{ }^{3} J_{H H}=7.7 \mathrm{~Hz}, \mathrm{H}_{\mathrm{dppe}}\right), 6.72\left(\mathrm{~d}, 4 \mathrm{H},{ }^{3} J_{H H}=8.4\right.$ $\mathrm{Hz}, \mathrm{H}_{\mathrm{Ar} \text { acetylene }}$ ), 4.04 (dt, $24 \mathrm{H},{ }^{3} J_{H H}=6.6 \mathrm{~Hz}, \mathrm{H}_{\text {Omethylene) }}, 2.66$ (br. s, $\left.8 \mathrm{H}, \mathrm{H}_{\text {dppe }}\right), 2.25$ (s, 6H, $\left.\mathrm{H}_{\mathrm{Me}}\right), 1.88-1.71\left(\mathrm{~m}, 28 \mathrm{H}, \mathrm{H}_{\text {aliphatic }}\right), 1.54(\mathrm{~m}$, $\mathrm{H}_{\text {aliphatic }}, 1.28$ (br. s, 205H, Haliphatic), 0.88 (m, 36H, Haliphatic); ${ }^{13} \mathrm{C} \mathrm{NMR}$ (75 MHz, $\mathrm{CD}_{2} \mathrm{Cl}_{2}$ ): $\delta=165.91,153.27,141.47,137.17,137.00,136.87$, $136.69,134.10,130.89,130.76,129.99,129.83,129.23,128.74$, $127.77,125.29,121.72,117.63,116.58,105.82,90.93,88.53,73.49$, 69.37, 31.94, $31.38\left(\mathrm{~m}^{1} \mathrm{~J}_{\mathrm{P}, \mathrm{C}}+{ }^{3} \mathrm{~J}_{\mathrm{P}, \mathrm{C}}=24 \mathrm{~Hz}, \mathrm{P}\left(\mathrm{CH}_{2}\right)_{2} \mathrm{P}\right), 30.40,29.77-$ 29.38 (br. m.), 26.16, 22.69, 13.87, 13.24. ${ }^{31} \mathrm{P}\left\{{ }^{1} \mathrm{H}\right\} \mathrm{NMR}(162 \mathrm{MHz}$, $\mathrm{CD}_{2} \mathrm{Cl}_{2}$ ): $\delta=$ 52.89. HRMS (ESI): $\mathrm{m} / z 1338.2289$ calcd for $\mathrm{C}_{258} \mathrm{H}_{378} \mathrm{~N}_{4} \mathrm{O}_{16} \mathrm{P}_{4}{ }^{102} \mathrm{Ru}\left[M^{3+}\right.$ ]; found: 1338.2321 . IR $\left(\mathrm{cm}^{-1}\right): 3432\left(v_{\mathrm{N}}-\right.$ H), $2921\left(v_{\mathrm{C}-\mathrm{H}}\right), 2054\left(v_{\mathrm{C}=\mathrm{C}}\right), 1636\left(v_{\mathrm{C}=\mathrm{O}}\right), 1583\left(v_{\mathrm{C}=\mathrm{C}}\right) . \lambda_{\max }(\varepsilon): 402 \mathrm{~nm}$ $\left(\right.$ solvent $=$ DCM, $\left.63000 \mathrm{~L} \mathrm{~mol}^{-1} \mathrm{~cm}^{-1}\right)$.

\section{ASSOCIATED CONTENT}

\section{Supporting Information}

The Supporting Information is available free of charge on the ACS Publications website.

Precursor synthetic procedures. NMR spectra of $\mathbf{L}^{\mathbf{2}}, \mathbf{5}, \mathbf{R} \mathbf{u}_{1}$ and $\mathbf{R} \mathbf{u}_{2}$. Comparative NMR studies of $\mathbf{R} \mathbf{u}_{1}$ and $\mathbf{R} \mathbf{u}_{2}$ in $\mathbf{C D}_{2} \mathrm{Cl}_{2}$. VTNMR monitoring for compounds $\mathbf{L}^{2}$ and $\mathbf{R} \mathbf{u}_{2}$. Gel formation procedure and corresponding summary of the gel properties. SEM images. Absorption spectrum of $\mathbf{R} \mathbf{u}_{1}$ and $\mathbf{R} \mathbf{u}_{2}$. $\mathrm{CV}$ of $\mathbf{R} \mathbf{u}_{1}$ and $\mathbf{R} \mathbf{u}_{2}$. DFT and TDDFT calculations for $\mathbf{R} \mathbf{u}_{1}$ and $\mathbf{R} \mathbf{u}_{2}$.

\section{AUTHOR INFORMATION}

\section{Corresponding Author}

* olivier.galangau@ univ-rennes1.fr

* stephane.rigaut@univ-rennes1.fr

\section{Notes}

The authors declare no competing financial interest.

\section{ACKNOWLEDGMENT}

The authors thank the Universite de Rennes 1 and the CNRS for support. The authors are grateful to Dr. Camerel for the fruitful discussions about the gel formation. This work was granted access to the computing resources of CINES (Montpellier, allocation 2019-A0060810728 and 2020-AP010811752 awarded by GENCI). The authors also thank F. Gouttefangeas and L. Joanny from the CMEBA (Centre de Microscopie Electronique à Balayage et microAnalyse, Rennes) for assistance in recording SEM images.

\section{REFERENCES}

1. Amabilino, D. B.; Smith, D. K.; Steed, J. W. Supramolecular materials. Chem. Soc. Rev. 2017, 46, 2404-2420.

2. Li, Q.; Li, Z. Molecular Packing: Another Key Point for the Performance of Organic and Polymeric Optoelectronic Materials. Acc. Chem. Res. 2020, 53, 962-973.

3. Hasegawa, M.; Iyoda, M. Conducting supramolecular nanofibers and nanorods. Chem. Soc. Rev. 2010, 39, 2420-2427.

4. Wang, S.; Kappl, M.; Liebewirth, I.; Muller, M.; Kirchhoff, K.; Pisula, W.; Mullen, K. Organic field-effect transistors based on highly ordered single polymer fibers. Adv. Mater. 2012, 24, 417-420.

5. Faramarzi, V.; Niess, F.; Moulin, E.; Maaloum, M.; Dayen, J. F.; Beaufrand, J. B.; Zanettini, S.; Doudin, B.; Giuseppone, N. Lighttriggered self-construction of supramolecular organic nanowires as metallic interconnects. Nat. Chem. 2012, 4, 485-490. 
6. Weiss, R. G. The past, present, and future of molecular gels. What is the status of the field, and where is it going? J. Am. Chem. Soc. 2014, 136, 7519-7530.

7. Kartha, K. K.; Babu, S. S.; Srinivasan, S.; Ajayaghosh, A. Attogram sensing of trinitrotoluene with a self-assembled molecular gelator. J. Am. Chem. Soc. 2012, 134, 4834-4841.

8. Babu, S. S.; Praveen, V. K.; Ajayaghosh, A. Functional pigelators and their applications. Chem. Rev. 2014, 114, 1973-2129.

9. Babu, S. S.; Prasanthkumar, S.; Ajayaghosh, A. Selfassembled gelators for organic electronics. Angew. Chem. Int. Ed. 2012, 51, 1766-1776.

10. Yang, X.; Zhang, G.; Zhang, D. Stimuli responsive gels based on low molecular weight gelators. J. Mater. Chem. 2012, 22, 3850 .

11. Zhang, L.; Li, S.; Squillaci, M. A.; Zhong, X.; Yao, Y.; Orgiu, E.; Samori, P. Supramolecular Self-Assembly in a Submicrometer Electrodic Cavity: Fabrication of Heat-Reversible pi-Gel Memristor. J. Am. Chem. Soc. 2017, 139, 14406-14411.

12. Draper, E. R.; Adams, D. J. Photoresponsive gelators. Chem. Commun. 2016, 52, 8196-8206.

13. Sun, Z.; Huang, Q.; He, T.; Li, Z.; Zhang, Y.; Yi, L. Multistimuli-responsive supramolecular gels: design rationale, recent advances, and perspectives. Chem. Phys. Chem 2014, 15, 2421-2430.

14. Yan, X.; Wang, F.; Zheng, B.; Huang, F. Stimuli-responsive supramolecular polymeric materials. Chem. Soc. Rev. 2012, 41, 6042 6065 .

15. Zhang, J.; Su, C.-Y. Metal-organic gels: From discrete metallogelators to coordination polymers. Coord. Chem. Rev. 2013 257, 1373-1408.

16. Fages, F. Metal coordination to assist molecular gelation. Angew. Chem. Int. Ed. 2006, 45, 1680-1682.

17. Tam, A. Y.; Yam, V. W. Recent advances in metallogels. Chem. Soc. Rev. 2013, 42, 1540-1567.

18. Dastidar, P.; Ganguly, S.; Sarkar, K. Metallogels from Coordination Complexes, Organometallic, and Coordination Polymers. Chem. Asian J. 2016, 11, 2484-2498.

19. Gasnier, A.; Royal, G.; Terech, P. Metallo-supramolecular gels based on a multitopic cyclam bis-terpyridine platform. Langmuir 2009, 25, 8751-8762.

20. Kotova, O.; Daly, R.; dos Santos, C. M.; Boese, M.; Kruger, P. E.; Boland, J. J.; Gunnlaugsson, T. Europium-directed self-assembly of a luminescent supramolecular gel from a tripodal terpyridine-based ligand. Angew. Chem. Int. Ed. 2012, 51, 7208-7212.

21. Beatriu Escuder, F. R.-L. a. J. F. M. Supramolecular gels as active media for organic reactions and catalysis. New J. Chem. 2010, 34, 1044-1054.

22. Wang, X.; Han, Y.; Liu, Y.; Zou, G.; Gao, Z.; Wang, F. Cooperative Supramolecular Polymerization of Fluorescent Platinum Acetylides for Optical Waveguide Applications. Angew. Chem. Int. Ed. 2017, 56, 12466-12470.

23. Zhang, J. J.; Lu, W.; Sun, R. W.; Che, C. M. Organogold(III) supramolecular polymers for anticancer treatment. Angew. Chem. Int. Ed. 2012, 51, 4882-4886.

24. Wang, J.; Chen, Y.; Law, Y. C.; Li, M.; Zhu, M. X.; Lu, W.; Chui, S. S.; Zhu, N.; Che, C. M. Organo- and hydrogelators based on luminescent monocationic terpyridyl platinum(II) complexes with biphenylacetylide ligands. Chem. Asian J. 2011, 6, 3011-3019.

25. Anthony Yiu-Yan Tam, K. M.-C. W., and Vivian WingWah Yam. Unusual Luminescence Enhancement of Metallogels of Alkynylplatinum(II) 2,6-Bis(N-alkylbenzimidazol-2'-yl)pyridine Complexes upon a Gel-to-Sol Phase Transition at Elevated Temperatures. J .Am. Chem. Soc. 2009, 131, 6253-6260.

26. Tam, A. Y.; Wong, K. M.; Yam, V. W. Influence of counteranion on the chiral supramolecular assembly of alkynylplatinum(II) terpyridyl metallogels that are stabilised by Pt...Pt and pi-pi interactions. Chem. Eur. J. 2009, 15, 4775-4778.

27. Tam, A. Y.; Wong, K. M.; Zhu, N.; Wang, G.; Yam, V. W. Luminescent alkynylplatinum(II) terpyridyl metallogels stabilized by Pt...Pt, pi-pi, and hydrophobic-hydrophobic interactions. Langmuir 2009, 25, 8685-8695.
28. Au, V. K.; Zhu, N.; Yam, V. W. Luminescent metallogels of bis-cyclometalated alkynylgold(III) complexes. Inorg. Chem. 2013, 52 , 558-567.

29. Tam, A. Y.; Wong, K. M.; Wang, G.; Yam, V. W. Luminescent metallogels of platinum(II) terpyridyl complexes: interplay of metal...metal, pi-pi and hydrophobic-hydrophobic interactions on gel formation. Chem. Commun. 2007, 2028-2030.

30. Camerel, F.; Ziessel, R.; Donnio, B.; Bourgogne, C.; Guillon, D.; Schmutz, M.; Iacovita, C.; Bucher, J. P. Formation of gels and liquid crystals induced by PtPt and pi-pi* interactions in luminescent sigma-alkynyl platinum(II) terpyridine complexes. Angew. Chem. Int. Ed. 2007, 46, 2659-2662.

31. Wu, H.; Zheng, J.; Kjoniksen, A. L.; Wang, W.; Zhang, Y.; Ma, J. Metallogels: Availability, Applicability, and Advanceability. Adv. Mater. 2019, 31, 1806204

32. Luo, L.; Benameur, A.; Brignou, P.; Choi, S. H.; Rigaut, S.; Frisbie, C. D. Length and Temperature Dependent Conduction of Ruthenium-Containing Redox-Active Molecular Wires. J. Phys. Chem. C 2011, 115, 19955-19961.

33. Meng, F.; Hervault, Y. M.; Shao, Q.; Hu, B.; Norel, L.; Rigaut, S.; Chen, X. Orthogonally modulated molecular transport junctions for resettable electronic logic gates. Nat. Commun. 2014, 5, 3023.

34. Schwarz, F.; Kastlunger, G.; Lissel, F.; Egler-Lucas, C.; Semenov, S. N.; Venkatesan, K.; Berke, H.; Stadler, R.; Lortscher, E. Field-induced conductance switching by charge-state alternation in organometallic single-molecule junctions. Nat. Nanotechnol. 2016, 11, $170-176$.

35. Tanaka, Y.; Kato, Y.; Sugimoto, K.; Kawano, R.; Tada, T.; Fujii, S.; Kiguchi, M.; Akita, M. Single-molecule junctions of multinuclear organometallic wires: long-range carrier transport brought about by metal-metal interaction. Chem. Sci. 2021, 12, 43384344.

36. Milan, D. C.; Vezzoli, A.; Planje, I. J.; Low, P. J. Metal bis(acetylide) complex molecular wires: concepts and design strategies. Dalton Trans. 2018, 47, 14125-14138.

37. Naher, M.; Bock, S.; Langtry, Z. M.; O’Malley, K. M.; Sobolev, A. N.; Skelton, B. W.; Korb, M.; Low, P. J. Synthesis, Structure and Physical Properties of "Wire-like" Metal Complexes. Organometallics 2020, 39, 4667-4687.

38. Zhang, L.-Y.; Duan, P.; Wang, J.-Y.; Zhang, Q.-C.; Chen, Z.-N. Ruthenium(II) as Conductive Promoter To Alleviate Conductance Attenuation in Oligoynyl Chains. J. Phys. Chem. C 2019, $123,5282-5288$.

39. Wuttke, E.; Pevny, F.; Hervault, Y. M.; Norel, L.; Drescher, M.; Winter, R. F.; Rigaut, S. Fully delocalized (ethynyl)(vinyl)phenylene bridged triruthenium complexes in up to five different oxidation states. Inorg. Chem. 2012, 51, 1902-1915.

40. Ou, Y. P.; Zhang, J.; Zhang, M. X.; Zhang, F.; Kuang, D.; Hartl, F.; Liu, S. H. Bonding and Electronic Properties of Linear Diethynyl Oligothienoacene-Bridged Diruthenium Complexes and Their Oxidized Forms. Inorg. Chem. 2017, 56, 11074-11086.

41. Ying, J. W.; Liu, I. P.; Xi, B.; Song, Y.; Campana, C.; Zuo, J. L.; Ren, T. Linear trimer of diruthenium linked by butadiyn-diyl units: a unique electronic wire. Angew. Chem. Int. Ed. 2010, 49, 954 957.

42. Mulas, A.; Hervault, Y. M.; He, X.; Di Piazza, E.; Norel, L.; Rigaut, S.; Lagrost, C. Fast Electron Transfer Exchange at SelfAssembled Monolayers of Organometallic Ruthenium(II) sigmaArylacetylide Complexes. Langmuir 2015, 31, 7138-7147.

43. Colombo, A.; Dragonetti, C.; Roberto, D.; Ugo, R.; Falciola, L.; Luzzati, S.; Kotowski, D. A Novel Diruthenium Acetylide Donor Complex as an Unusual Active Material for Bulk Heterojunction Solar Cells. Organometallics 2011, 30, 1279-1282.

44. Roberts, R. L.; Schwich, T.; Corkery, T. C.; Cifuentes, M. P.; Green, K. A.; Farmer, J. D.; Low, P. J.; Marder, T. B.; Samoc, M.; Humphrey, M. G. Organometallic Complexes for Nonlinear Optics. 45. Dispersion of the Third-Order Nonlinear Optical Properties of Triphenylamine-Cored Alkynylruthenium Dendrimers. Adv. Mater 2009, 21, 2318-2322. 
45. Simpson, P. V.; Watson, L. A.; Barlow, A.; Wang, G.; Cifuentes, M. P.; Humphrey, M. G. Record Multiphoton Absorption Cross-Sections by Dendrimer Organometalation. Angew. Chem. Int. Ed. 2016, 55, 2387-2391.

46. Samoc, M.; Morrall, J. P.; Dalton, G. T.; Cifuentes, M. P.; Humphrey, M. G. Two-photon and three-photon absorption in an organometallic dendrimer. Angew. Chem. Int. Ed. 2007, 46, 731-733.

47. Zhang, X.; Shi, L.; Fox, M. A.; Barlow, A.; Morshedi, M.; Cifuentes, M. P.; Humphrey, M. G.; Mongin, O.; Paul, F.; Paul-Roth, C. O. Nonlinear optical properties of meso-Tetra(fluorenyl)porphyrins peripherally functionalized with one to four ruthenium alkynyl substituents. Dyes and Pigments 2021, 188, 109155.

48. Triadon, A.; Grelaud, G.; Richy, N.; Mongin, O.; Moxey, G. J.; Dixon, I. M.; Yang, X.; Wang, G.; Barlow, A.; Rault-Berthelot, J.; Cifuentes, M. P.; Humphrey, M. G.; Paul, F. Linear and Third-Order Nonlinear Optical Properties of $\mathrm{Fe}(\eta 5-\mathrm{C} 5 \mathrm{Me} 5)(\kappa 2$-dppe)- and trans$\mathrm{Ru}(\kappa 2$-dppe)2-Alkynyl Complexes Containing 2-Fluorenyl End Groups. Organometallics 2018, 37, 2245-2262.

49. Norel, L.; Di Piazza, E.; Feng, M.; Vacher, A.; He, X.; Roisnel, T.; Maury, O.; Rigaut, S. Lanthanide Sensitization with Ruthenium Carbon-Rich Complexes and Redox Commutation of NearIR Luminescence. Organometallics 2014, 33, 4824-4835.

50. Al Sabea, H.; Norel, L.; Galangau, O.; Hijazi, H.; Metivier, R.; Roisnel, T.; Maury, O.; Bucher, C.; Riobe, F.; Rigaut, S. Dual Light and Redox Control of NIR Luminescence with Complementary Photochromic and Organometallic Antennae. J. Am. Chem. Soc. 2019, 141, 20026-20030.

51. Norel, L.; Bernot, K.; Feng, M.; Roisnel, T.; Caneschi, A.; Sessoli, R.; Rigaut, S. A carbon-rich ruthenium decorated dysprosium single molecule magnet. Chem. Commun. 2012, 48, 3948-3950.

52. Vives, G.; Tour, J. M. Synthesis of a nanocar with organometallic wheels. Tet. Lett. 2009, 50, 1427-1430.
53. Kadjane, P.; Starck, M.; Camerel, F.; Hill, D.; Hildebrandt, N.; Ziessel, R.; Charbonniere, L. J. Divergent approach to a large variety of versatile luminescent lanthanide complexes. Inorg. Chem. 2009, 48, 4601-4603.

54. Camerel, F.; Donnio, B.; Bourgogne, C.; Schmutz, M.; Guillon, D.; Davidson, P.; Ziessel, R. Tuning the thermotropic and lyotropic properties of liquid-crystalline terpyridine ligands. Chem. Eur. J. 2006, 12, 4261-4274.

55. Céline Olivier, B. K., Daniel Touchard,Stéphane Rigaut. Redox-Active Molecular Wires Incorporating Ruthenium(II) $\sigma$ Arylacetylide Complexes for Molecular Electronics. Organometallics 2008, 27, 509-518.

56. Camerel, F.; Ulrich, G.; Ziessel. R. New Platforms Integrating Ethynyl-Grafted Modules for Organogels and Mesomorphic Superstructures. Org. Lett. 2004, 6, 4171-4174.

57. Zhang, J.; Xu, X.-D.; Chen, L.-J.; Luo, Q.; Wu, N.-W.; Wang, D.-X.; Zhao, X.-L.; Yang, H.-B. Platinum Acetylide Complexes Containing Iptycene as Cores: A New Family of Unexpected Efficient Organometallic Gelators. Organometallics 2011, 30, 4032-4038.

58. Falivene, L.; Cao, Z.; Petta, A.; Serra, L.; Poater, A.; Oliva, R.; Scarano, V.; Cavallo, L. Towards the online computer-aided design of catalytic pockets. Nat. Chem. 2019, 11, 872-879.

59. Mabesoone, M. F. J.; Palmans, A. R. A.; Meijer, E. W. Solute-Solvent Interactions in Modern Physical Organic Chemistry: Supramolecular Polymers as a Muse. J. Am. Chem. Soc. 2020, 142 , 19781-19798.

\section{For Table of Content only}

$\mathrm{A} \mathrm{Ru}{ }^{\mathrm{II}}$ bis-acetylide complex is able to form organic gels for the first time, thanks to a dedicated molecular design.

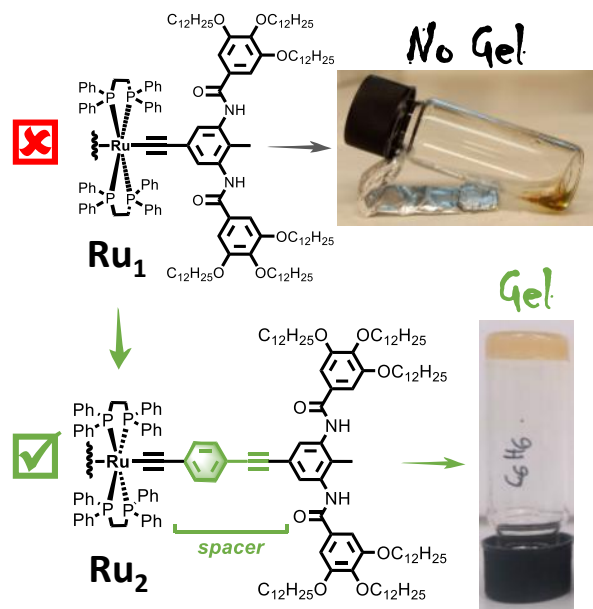

